\title{
Downcycling and Upcycling in Rehabilitation and Adaptive Reuse of Pre-Existing Buildings: Re-Designing Technological Performances in an Environmental Perspective
}

\author{
Antonello Monsù Scolaro ${ }^{1, *(\mathbb{D})}$ and Stefania De Medici ${ }^{2, *(\mathbb{D})}$ \\ 1 Department of Architecture, Design and Urban Planning, University of Sassari, 07100 Sassari, Italy \\ 2 Department of Civil Engineering and Architecture, University of Catania, 96100 Siracusa, Italy \\ * Correspondence: amscolaro@uniss.it (A.M.S.); stefania.demedici@unict.it (S.D.M.)
}

check for

updates

Citation: Scolaro, A.M.; De Medici, S. Downcycling and Upcycling in Rehabilitation and Adaptive Reuse of Pre-Existing Buildings: Re-Designing Technological Performances in an Environmental Perspective. Energies 2021, 14, 6863. https://doi.org/ $10.3390 /$ en14216863

Academic Editors: Alfredo Guardo Zabaleta and Korjenic Azra

Received: 16 September 2021

Accepted: 17 October 2021

Published: 20 October 2021

Publisher's Note: MDPI stays neutral with regard to jurisdictional claims in published maps and institutional affiliations.

Copyright: (c) 2021 by the authors. Licensee MDPI, Basel, Switzerland. This article is an open access article distributed under the terms and conditions of the Creative Commons Attribution (CC BY) license (https:/ / creativecommons.org/licenses/by/ $4.0 /)$.

\begin{abstract}
The abandonment of the built heritage, as a result of functional or technological obsolescence or as a consequence of cultural, social, and economic trends, is steadily increasing. This great number of buildings, worldwide spread, offers a huge opportunity to reduce the environmental impacts related to the construction industry. Nonetheless, the recovery and reuse interventions that require the implementation of residual technological performance, to accommodate new uses, are not always environmentally neutral. Therefore, a new design approach needs to be developed so as to improve the buildings' technological performance and enhance resources and energy already incorporated in buildings. The circular economy principles in the building sector, performance-based building design together with downcycling and upcycling theories are applied to develop a methodology aiming to reduce the environmental impacts within the rehabilitation and refurbishment design process. Starting from the building analysis phase (historical, material, construction) residual performance is evaluated; then the design phase demonstrates that, according to downcycling and upcycling design strategies applied on building components and materials, it is possible improving the building to the required new uses while minimizing transformations and effectively reducing related environmental impacts. The reduction of environmental impacts depends on a careful assessment of the residual technological and structural performance that the building still provides, by involving limited performance implementations to balance rehabilitation needs and environmental protection goals.
\end{abstract}

Keywords: building recovery; energy embodied; downcycling; upcycling; environmental balance

\section{Introduction}

The issue of abandonment of the building assets is increasingly widespread. The causes of this phenomenon are manifold, but the overall effect is the waste of resources and the spread of decay due to disrepair [1]. In the European Union, the number of dwellings was approximately 206.7 million at the beginning of the new millennium [2]. A significant part of this real estate was unused, with percentages exceeding $20 \%$ in the Mediterranean area [3]. In Italy, for instance, data on vacant dwellings show that the percentage significantly increased from $5.37 \%$ in 1951 to $20.04 \%$ in 1981 , and then fluctuated between the latter value and $22.66 \%$ in 2011 [3].

The causes of the abandonment can be endogenous, i.e., due to the poor suitability of the buildings compared to the evolution of the use requirements, or due to changing conditions in the context.

Considering the building independently from its context, the main cause of abandonment is obsolescence, i.e., the process of decline in its performance. Indeed, according to Thomsen et al., "Obsolescence is a serious threat for built property and the physical, economic and societal investments incorporated in buildings. Insight in obsolescence is 
also important because of the ongoing paradigm shift from new construction to maintenance and improvement of the existing housing stock. This shift calls for a comprehensive approach to obsolescence" [4]. Studies concerning obsolescence usually focus only on a single issue, addressing physical, social, or economic implications, or merely technical aspects. Nevertheless, when considering the built heritage as a resource with multiple values, it is necessary to consider the multiple issues involved [5].

Demolition and further reconstruction are not economically or ecologically viable solutions. Therefore, renovation and retrofit strategies are needed to address the issue of the aging building stock in developed countries [6].

In the Western world, over the last two decades, the construction industry is progressively focusing its core business from the construction of new buildings (including the production of new materials and components) to the renovation of the existing building stock [7-16]. European data on the variation of investment in construction in real terms on the previous year in the construction industry show that, despite the overall slowdown caused by the SARS-CoV19 pandemic, the renovation sector is proving to be steadier and more attractive than new construction (new house building investment variation is $+3.1 \%$ in $2019,-7.8 \%$ in 2020 and $+4.8 \%$ in 2021 ; renovation variation is $+2.9 \%$ in 2019 , $-3.7 \%$ in 2020 and $+5.7 \%$ in 2021) [17]. This trend, which is growing over time, is also influenced by European policies oriented towards the Renovation Wave for Europe [18]. It reflects demographic trends and can be driven by a large amount of real estate abandoned for a variety of reasons, by the high demand of the real estate market in central or valuable urban areas-where demolition and rebuilding are often not allowed due to cultural and landscape constraints-as well as by the need to reduce the consumption of land and raw materials. Indeed, the environmental impact of buildings can be assessed in terms of energy consumption for extraction, transport, processing, installation, and wastes produced, and can be compared to the building's performance throughout its life cycle. Some authors analyzed the costs and benefits resulting from two different intervention strategies-demolition and reconstruction vs. renovation-for buildings that need to be adapted to new use requirements [19]. High durability and, more generally, the ability of a building to ensure adequate long-term efficiency is consistent with sustainability goals, as it reduces the consumption of energy and other resources as well as the associated level of emissions. This view has led to the development of a great deal of research on Life Cycle Assessment in buildings, also in relation to energy-saving goals for buildings [20-30].

Consistent with these criteria and looking at the opportunity to exploit resources and energies embedded in existing buildings by improving their remaining performance, the paper aims at defining a methodology to evaluate alternative interventions for performance upgrading of the building system, according to sustainability objectives. This methodology considers the downcycling and upcycling of construction materials and components as opportunities to reduce environmental impact.

The paper consists of 5 Sections. Section 2 discusses the background leading to the issue of downcycling and upcycling strategies in building renovation. The background is organized in three sub-sections, which deal with the following key issues: the circular economy approach in the constructions sector; the Performance-Based Building Design in building renovation; the down-cycling, up-cycling, and up-sizing strategies to reduce the environmental impacts while improving the performance levels of existing buildings.

Section 3 outlines the method developed to define assessment criteria for improving buildings' performance through design solutions with low environmental impact. Section 4 presents the selected case study to test the methodology in accordance with the theoretical and empirical background; Section 5 presents the results and discusses possible design alternatives; Section 6 concludes by presenting the limitations of the experiment and future implementations. 


\section{Background}

\subsection{Circular Economy and the Construction Process}

As a consequence of the economic crisis starting in the late 2000s, the need for new approaches to sustainable development led to focusing on alternative economic models. The goal to overcome linear development processes and look for new solutions to balance the ambitions of economic growth and the protection of the environment led to implementing circular production processes. The circular economy (CE) can be defined as "an industrial economy that is restorative or regenerative by intention and design" [31]. In the words of Michael Lieder and Amir Rashid, the concept of circular economy "is to an increasing extent treated as a solution to a series of challenges such as waste generation, resource scarcity, and sustaining economic benefits. Nevertheless, the concept of circularity is not novel as such. Specific circumstances and motivations have stimulated ideas relevant to circularity in the past through activities such as reuse, remanufacturing or recycling" [32] (p. 36). Whereas handicraft production processes did not produce waste or unusable materials [33], after the industrial revolution, disposable products (characterized by a linear consumption model) started to spread [32]. Nonetheless, during the Second World War, scarcity of resources led to remanufacturing. This process brings durable products back to life. Remanufacturing continued to develop after the war as a result of its economic benefits and was relaunched as environmental pollution problems worsened [34]. In particular, pollution caused by industrial development is perceived as a priority problem in China, leading the government to define a new development strategy in 2002 and approve the 'Circular Economy Promotion Law of the People's Republic of China', in force since 2009 [35-37].

Environmental protection problems and the effects of the global economic crisis at the beginning of the new millennium led even the European Union to propose a circular economy model to manage production and consumption processes [38]. This approach aims to reduce resource scarcity and increase the life cycle of goods and products.

The evolution of production models towards circular processes can also be seen in the field of building production. Indeed, the first strategies of regenerative architectural design for the sustainable development of the landscape were first developed in the 1970s, when the main growth strategy was based on industrial systems and building prefabrication [39]. Through these strategies, the way of looking at sustainability in design changed, with practices focused "primarily on minimizing damage to the environment and human health, and using resources more efficiently" [40]. Since the 1990s, consistently with the principles of regenerative design, the scientific debate shows the need for a transition from a linear 'make-use-dispose' consumption model (cradle-to-grave) to a closed-loop model (cradle-tocradle). Sustainability is seen as a goal to link conservation and development achievements for the long-term benefit of society [41].

Based on these premises, a sustainable approach to the management of the existing buildings is based on the redevelopment and reuse, rather than new construction, to reduce the consumption of land, raw materials exploitation, and waste production. In particular, the key issue emerging from the scientific debate on the introduction of circularity principles in real estate production and management is the ability to find solutions to reuse existing resources while minimizing the impact on the environment.

\subsection{Performance-Based Building Design in Building Renovation}

In the mid-20th Century, the performance-based building design (PBBD) emerges from the need to foster innovation and international trade in building materials and products. PBBD is an approach to quality management in the construction industry, defined in 1982 by Gibson in CIB W60 Commission Report No. 64 as "the practice of thinking and working in terms of ends rather than means. It is concerned with what a building or building product is required to do, and not with prescribing how it is to be constructed" [42] (p. 4). To assess the quality of the building, the PBBD approach compares the user requirements with the performance levels that the building system and its components are able to provide. 
The assessment methods used allow the evaluation of whether the proposed design solutions meet the specified criteria by " $[$... ] quantification of the level of performance which a building material, assembly, system, component, design factor, or construction method must satisfy in order that the building meets all the goals established by society and the client" [43] (p. 19). All decisions are based on user needs, quantified in performance requirements, quality assessment, and building testing. In the three-year period 1998-2001, the CIB Board and Programme Committee launched the Proactive Programme on PerformanceBased Building [44]; The Performance-Based Building (PeBBu) was developed between 2001 and 2005 with funding from the European Commission. The proposed approach considers the building as a system consisting of interrelated subsystems and components which have a life cycle according to an organicist vision [45]. Design targets in construction are driven by user requirements (defined according to the needs of stakeholders, such as clients, users, manufacturers, etc.), specified with performance requirements.

The main steps of a performance-based building design process are briefing (identification of relevant user requirements), metadesign (transformation of user requirements into performance requirements and quantitative performance criteria), and the implementation of design and evaluation tools to assess compliance of design solutions with set requirements and criteria.

Implementing the performance-based approach to building renovation projects requires two additional steps in the PeBBu process, because the characteristics of the existing building should be considered [46]. The first of these steps is to analyze the building to be renovated, focusing on its remaining performance. This step aims to survey the performance levels provided by the building. The second step is to compare the performance requirements for new users with the remaining performance of the building to assess which performance needs to be improved and which new performance needs to be provided by the building to meet the requirements of the new use. Therefore, the renovation project will focus on those elements and subsystems that fail to meet the requirements of the new use. This approach aims to minimize the transformation of the building to be rehabilitated or reused, making the best use of the existing building. In the contemporary scientific debate, where development perspectives are closely linked to sustainability perspectives, the performance-based approach can also be reconsidered in building renovation processes. Improving the performance level or introducing new performance in existing buildings leads to the transformation or replacement of parts of the building system. In this perspective, the key issue to be addressed is the definition of systems and methodologies to balance the goals of performance efficiency with the goals of minimizing material and energy waste.

\subsection{Downcycling, Upcycling and Upsizing in Building Renovation: Energy and Materials}

On a European scale, since the Waste Framework Directive (2008/98/EC), recently repealed and replaced by Directive 2018/851/EU, wastes have assumed an increasing role in replacing raw materials in manufacturing processes. The Circular Economy Action Plan, launched in 2015, has progressively strengthened the transition towards the circular economy, focusing on priority objectives such as: (1) prudent and rational use of natural resources and energy; (2) keeping materials, components, and systems in use at their highest value as long as possible; (3) reduction of waste generated during production processes. Since it accounts for about $30 \%$ of all waste generated in the EU, construction, and demolition waste $(\mathrm{CDW})$ is identified as a priority sector within which recycling emerges as a crucial issue, as well as the challenge to push up the quality of its outputs.

Within the construction processes, the largest share of residues is generated during and after the use phase of a building (demolition wastes) and to a lesser degree during its production (construction wastes) [24]. An abandoned (or unused) building could be considered as a quarry [47] or a bank of materials [48] while offering the opportunity to reduce resource consumption and waste production [49]. However, the recovery and reuse or the recycling of pre-existing building materials and components are strongly conditioned 
by both their location and assembly, which also influence the demolition techniques that can be employed. Moreover, the material variety of a pre-existing building makes both the range of wastes and the flows of recoverable ones extremely variable, often making many possible methods coexist in the same operation [50,51]. Hence, in order to thoroughly valorize residual pre-existing materials, firstly should be necessary to assign the correct identification code in accordance with current sector regulations (by classifying them as a waste if required), then treating them depending upon their: (1) physical characteristics; (2) state of preservation; 3 ) residual technical performances [52]. Therefore, construction and demolition waste $(\mathrm{CDW})$ can be recycled and converted into reusable material: however, some authors consider recycling to be a process of reducing the value of the original ones, so they look at it as a downcycling process. Whereas, by considering cost-effectiveness and the reduction of related environmental impacts, other authors state that recycling is not a value-reducing process [53]. On the other hand, CDW could be also upcycled, i.e., treated in such a way as to create a product of higher quality or value than the original ones [54].

This over-valorization of waste is inspired by the efficient, circular metabolism of biological cycles and aims to replicate its positive effects in technical cycles as well [55]. Conceptually, this perspective is extraordinarily far-reaching, as it draws a structure of the material cycles that potentially solves the criticalities of the linear model [56]. However, even the upcycling process may require more energy than downcycling ones, so the environmental benefit cannot be assumed a priori, but only by comparing the production process with that of a similar product made from a virgin resource [57]. Similarly, downcycling can be an option with a positive environmental balance either when it is uneconomic or impossible to return materials to their original quality or when it can be an alternative solution to waste disposal or even to avoid the use of virgin resources $[58,59]$.

Within the design phase for adapting an existing building to new uses, the functional and spatial complexities lead to further operational difficulties because the needed modifications imply demolitions causing environmental balances that are not always positive due to the quantity of waste produced [60,61]. In fact, if ideally, an abandoned building is a potential quarry of building materials, the redevelopment-functional and performanceof spaces and building elements really determines a consistent material flow-in (news) and out (wastes) - to be managed. Therefore, according to Pomponi and Moncaster [62], considering only the meso- (building system) and micro-level (building components), the processes of upcycling and downcycling coexist both in order to implement the technological performance of the building to adapt it to new uses and to manage the environmental balance of the rehabilitation intervention. The latter thus also takes on the value of regenerative design [63] referring to Gunter Pauli's theory of 'upsizing' and the Zero Emission concept [64].

The regenerated building should be the result of a design approach that enhances pre-existing spatial qualities and residual technical performances of the building elements, reusing on-site all the material and energy resources incorporated in the building. By minimizing the input of new materials and the CDW produced, it will allocate the latter to the creation of value in another production chain (technical metabolism), to prolong the material's life in one form or another, which results in a reduced amount of virgin raw materials processed and a delay of the material eventually ending up in a landfill.

According to these remarks, the evaluation of design solutions for the performance upgrading of an existing building is a key issue to allow the selection of the preferable intervention among the design alternatives. Research in this field should lead to the definition of assessment criteria for design alternatives, based on multiple needs (meeting the building's use requirements, reducing the waste produced by the retrofit, minimizing additions involving the use of raw materials, minimizing the $\mathrm{CO}_{2}$ emissions generated by the intervention, etc.). 


\section{Methodology}

The research method is summarized in Figure 1 and is organized into four phases. The first phase consists of defining the research question and is based on the analysis of the conceptual framework, a critical literature review of the research on the subject, and the definition of the key issues resulting from the literature analysis. This phase allows the research hypothesis to be defined. The second phase consists of developing the research model, setting out the phases and activities, the methodologies to be adopted and the data to be collected, as well as drawing up a checklist of the process to be implemented for verifying the research hypotheses. The third and fourth phases are aimed at validating the methodology through a case study. In the third phase, the case study is analyzed and solutions to improve the performance of its building elements are defined, according to the requirements of the activities that will take place in the building after renovation. The assessment is based on a set of criteria to consider the environmental impact of alternative design solutions and allows the selection of the preferred solution.

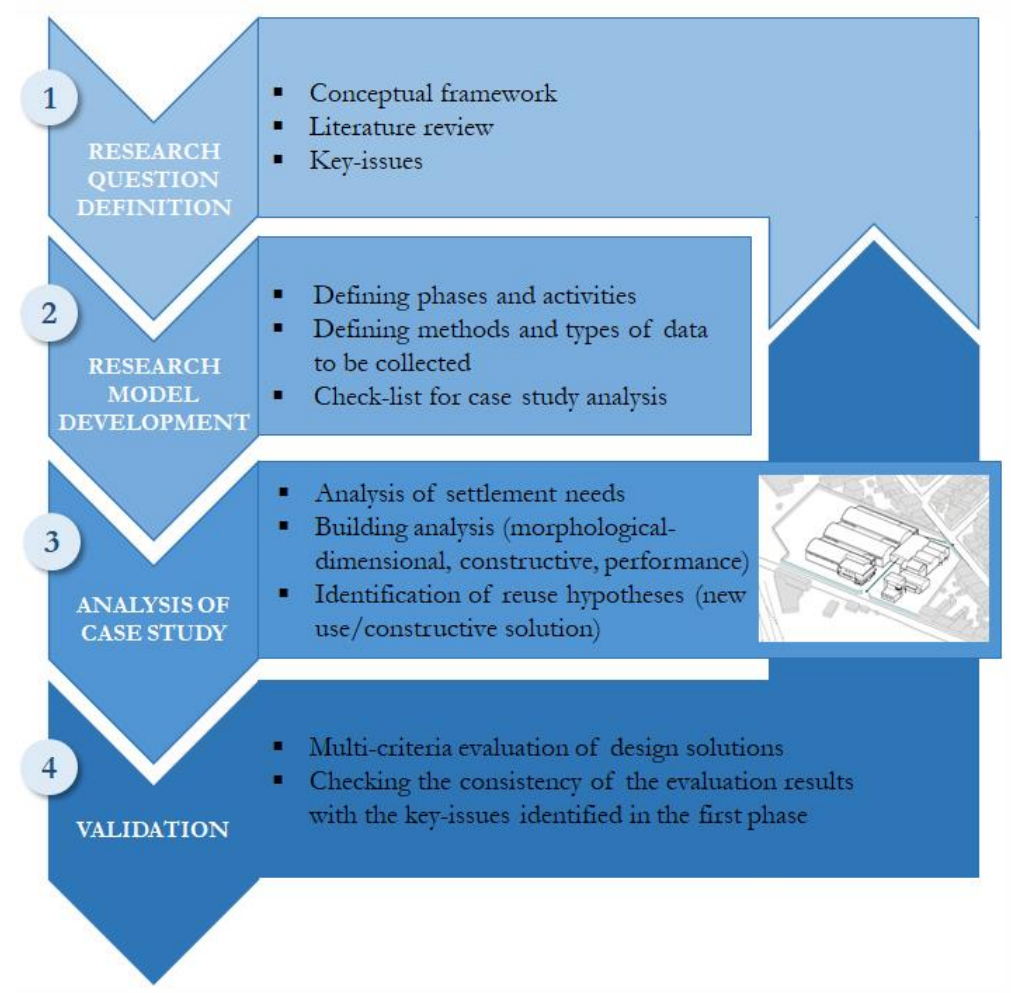

Figure 1. The research method.

The fourth stage of the research aims to validate whether the set of criteria is consistent with the key issues resulting from the analysis of the relevant scientific literature; furthermore, it allows us to verify research weaknesses or potential areas for further development.

The above-mentioned underlying considerations and the key issues identified led to the development of the methodology described below, which allows driving the choices of the renovation project to steer the development of the detailed design. In this phase the future use of the building has already been chosen, the intervention strategies (adaptive reuse, rehabilitation, maintenance) have been defined, as well as the performance requirements resulting from the activities that will be held in the building have been identified in the preliminary design phase.

The aim of the research is to develop a method for evaluating alternative design solutions for the performance improvement of building elements by combining the assessment of environmental impacts with the check of the remaining performance of the building $[65,66]$. Analyzing the building as a whole, the methodology involves assessing 
both the residual technological performance of the technical elements and the level of degradation of the materials in order to maintain and renovate as much of the existing material as possible. The methodology aims to combine the objectives of valorizing the embodied energy of construction materials with the objectives of reducing construction and demolition waste along the renovation design process of existing buildings. The aim is also to minimize environmental externalities through both a lower use of new materials (input) and a lower production of construction and demolition waste (output). The knowledge and analysis phase begins with the geometric survey of the building and ends with the analysis of the constituent materials, carried out on the scale of executive detail. Then, the quantity of existing material is estimated, broken down by type (stone; concrete; masonry blocks; wood; glass; plaster; insulation materials; roofing materials; etc.) in order to assess the quantities to be preserved (because they are still able to provide technological performance) and those to be demolished and possibly recovered (depending on the state of mechanical, physical and chemical degradation), according to the following activities:

- geometric survey

- analysis of the construction system, technical elements, and materials.

- calculation of the amount of material incorporated in the building;

- analysis of the state of decay

- calculation of the amount of material to be preserved and to be demolished (or recovered/recycled).

The assessment of Embodied Energy (EE) and Carbon Energy (EC) related to the 'from cradle to gate' phase of every single material is carried out on the basis of ICE $[67,68]$ data, expressed in $\mathrm{MJ} / \mathrm{Kg}$ and in $\mathrm{KgCO} 2 \mathrm{eq} / \mathrm{kg}$ of product (concrete; wood; masonry blocks; floors; etc.), transformed into $\mathrm{MJ}$ and $\mathrm{KgCO} 2 \mathrm{eq}$ referred to the square meter for each building element analyzed. The values of the eco-inventory have been transformed by means of simple arithmetic operations starting from the specific weight; density; thickness and volume of every single material constituting the building element, in order to obtain a more comprehensible unit of measurement for the designer, useful for autonomously evaluating the environmental impacts associated with the technical redevelopment choices.

Starting from the hypothesis that each new use implies the adaptation of the building's technological performance, for each building element, in this phase, some parameters were identified in order to better control the environmental impact related to the performance improvement starting from the original situation of the pre-existing buildings:

- the amount of Embodied Energy $\left(\mathrm{EE}_{\mathrm{bm}}\right)$ and Carbon Energy $\left(\mathrm{EC}_{\mathrm{bm}}\right)$ for each construction material and building component. These dimensions are expressed for methodological clarity in $\mathrm{MJ}$ and in $\mathrm{KgCO}_{2}$ eq both per unit weight and per unit area;

- the amount of material removed classified by type, and the related energy rates $\left(\mathrm{EE}_{\mathrm{dem}}\right.$ and $\mathrm{EC}_{\mathrm{dem}}$ ) potentially lost;

- the amount of material that can be reused (on-site) or recycled through downcycling or upcycling processes and the amount of related energy that is not wasted (EE rec and $\left.\mathrm{EC}_{\mathrm{rec}}\right)$.

This first phase of analysis allows the defining of a preliminary performance profile of the building to be retrofitted, based on the quantity of material and energy that can be optimized in relation to the residual technological performance $\left(\mathrm{TP}_{\text {res }}\right)$ of the technical elements and to the performance requirements resulting from the new use, net of demolition and removal of unsuitable materials.

Based on previously defined new functional layouts of the activities that will be performed in the building (among the possible use alternatives and the functional organization), the new performance requirement levels $\left(\mathrm{TP}_{\text {new }}\right)$ to be met by the building are defined (needed dimensions, structural strength, thermal insulation, systems supply, etc.) and the possible technological alternatives to retrofit the building elements are considered. The original performance efficacy is expressed in percentage and is obtained from the ratio 
between the remaining technological performance $\left(\mathrm{TP}_{\text {res }}\right)$ and performance requirements of the new use $\left(\mathrm{TP}_{\text {new }}\right)$.

In fact, in order to reduce the environmental impacts of the renovation, the choice of new uses is based on the remaining technological performance and therefore on the evaluation of the energy needed to improve performance to the new levels of performance requirements. The performance status of the existing building guides the architectural decision-making in the renovation design [69]; by comparing different use alternatives or different layouts of the activities to be located in the building, according to the associated requirements and remaining performance, the design solution that needs the lowest performance improvement can be selected, thus generating the lowest associated environmental impacts $[19,70]$.

Effectively, the technological design alternatives are compared and the increase in embodied energy and carbon energy is calculated. In the overall energy balance of the selected solution, the amounts of demolished and reused material (downcycling or upcycling) should be considered, and the associated energy rate $\left(\mathrm{EE}_{\mathrm{dem}}\right.$ and $\left.\mathrm{EC}_{\mathrm{dem}}\right)$ positively contribute to reducing the environmental impacts of the adopted solution.

When comparing two or more intervention alternatives, for the same new level of technological requirement of a building element, the one with the lowest increase of embodied energy will be the preferred one.

Moreover, if the residual EE of the building element is the amount of matter that has not completed its life cycle, the value of $100 \%$ would mean that the building element is in a good state of conservation and all the existing material is effective whether compared to the performance required. A value of $0 \%$ would mean that there is no performance or that the building element has to be entirely demolished and replaced.

In this sense, the introduction of environmental indicators associated both with each technical element and with the building as a whole makes it possible to innovate the technological and performance analysis of the built heritage from an environmental point of view. The detailed study of the construction elements supports the redevelopment alternatives towards solutions that enhance the existing material by reducing the input of new material, incorporated energy, and emitted $\mathrm{CO}_{2}$ [70].

\section{Case Study}

The case study is the former industrial compound of the Ente Nazionale Risi (Founded in 1923) in Oristano, Sardinia (Italy). The knowledge project is organized on multiple scales, ranging from the study of the urban context to the analysis of the building system and its performance, up to the in-depth study of construction details. The analysis of the local context and the preliminary morphological and dimensional surveys of the building led to the definition of the new use. The development of the functional layout led to a framework of needs and performance requirements to be met, for each technical element, according to the activities located in each space. In this phase, the performance-based analysis of the building's technical elements is carried out to compare the remaining performance levels of each element with the performance requirements of the activities that will be performed in the building. This analysis allows the identification of those elements of the building that need to be replaced or transformed to suit the use. Several alternative design solutions can be defined to improve the performance levels of these elements. The research has led to the definition of a set of criteria for considering the environmental impact of alternative design solutions when selecting the preferred one.

\subsection{The Former Industrial Compound of the Ente Nazionale Risi in Oristano (Sardinia, Italy)}

Rice arrived in Europe from the 7th century onwards and arrived in Italy in the 15th century from the Far East, maybe as a result of the Crusades or through traders in ancient Venice. It spread very quickly in Italy and led to the creation of an efficient production chain. The area used for rice cultivation progressively increased, particularly in northern Italy, in the Po Valley, a region rich in water and marshland. Rice production uses factories 
and other buildings that over time shaped the landscape, culture, and economy of the area. Today, the old factories are largely abandoned; they are cultural resources, as industrial archaeology heritage, as well as buildings to be reused for sustainability purposes, and they are opportunities for design experimentation in rehabilitation and adaptive reuse.

In the province of Oristano, Sardinia, rice production quickly spread thanks to the wide marshy plains rich in water. As a result of the land reclamation in the early 1900s, the province of Oristano became the fifth province in Italy in terms of the quantity of annual rice production (with $89.7 \%$ of Sardinia's rice-growing areas and a production of 250,000 quintals of rice per year).

The former industrial complex of the Ente Nazionale Risi is located on the eastern edge of Oristano, near the level crossing of the urban railway line. The compound was built in 1954, covering an area of 7000 square meters, $65 \%$ of which is covered by buildings. The building was originally made up of three large, aligned warehouses connected by two galleries; three additional smaller warehouses; an office building, and a gatehouse (later converted into offices and housing). In 1971, the complex was expanded to store the increasing quantities of rice produced: an arcade was built between the milling building and the rice storage building to facilitate the loading and storage of the rice. A further shed was built between the milling building and the gatehouse, with a light roof supported by metal trusses and load-bearing concrete block walls. Further alterations were introduced over the years to adapt the production activity to the continuous technological and organizational developments of the company. The industrial compound was used for rice production until 1992. The gatehouse was abandoned more recently, in 2014, as shown in Figure 2.

Historical evolution

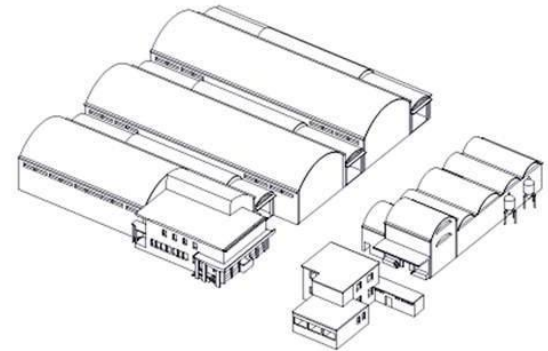

1954

Abandonment phases

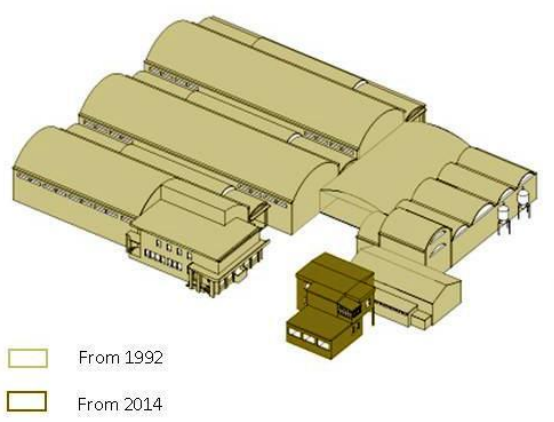

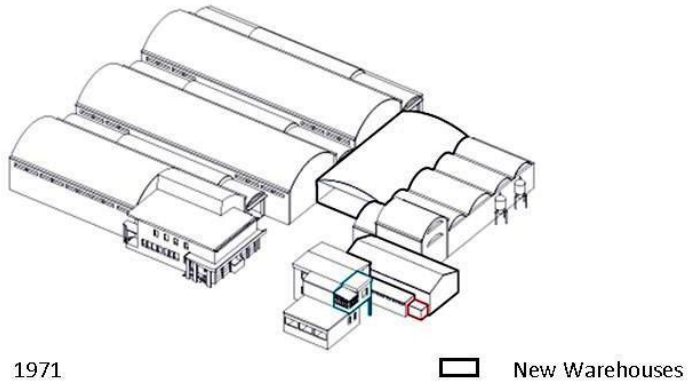

Uses analysis

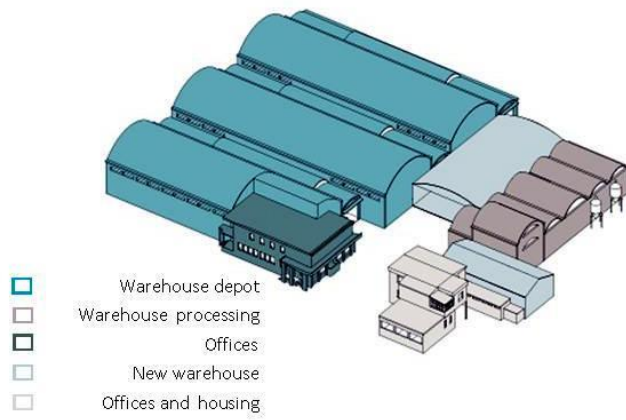

Figure 2. Building additions from 1954 to 1971 (top), abandonment, and layout of the former activities (bottom).

\subsection{Flexibility of Use as a Requirement for Circularity in the Adaptive Reuse of the Former Industrial Complex}

Since 2017, the Oristano City Council has undertaken a wide-ranging process of functional redevelopment of the urban area which includes the former industrial site of the Ente Nazionale Risi. This district is characterized by low-quality housing (built between the 1960s and 1970s) and extensive brownfield sites, which also require a comprehensive 
rehabilitation within a broader framework of urban regeneration [71,72]. The analysis of the urban area shows the presence of housing, schools, and several small retail activities (stores, cafés, and restaurants); public transport is available in the area, which can also be easily reached by car; nonetheless, cultural and social facilities, parks, public open spaces, and bicycle lanes are missing. The area of the former industrial complex of the Ente Nazionale Risi is enclosed by a boundary wall, once necessary to protect the production site, now an obstacle to public access.

Today, the former industrial plant appears as the result of the progressive addition of buildings (different in size, construction characteristics, and materials) as a result of changes in production processes over the years: this variety of volumes, as well as the complex's layout, allow for different uses, combined together, to preserve the memory of the production history of this place. Therefore, after analyzing the profile of potential users and the needs of the local community through a direct survey of residents as confirmed by previous research, the former industrial complex has been reused as a multifunctional hub for services to citizens: the adaptive reuse project could generate a pole of urban attraction, starting a process of regeneration of the area as shown in Figures 3 and 4.

The renovation intervention aims at the following goals: fostering the spatial and functional flexibility, as well as preserving the identity of the complex (i); keeping the buildings in use for as long as possible and, through limited alterations and reversible additions, adapting them to the needs of the community (ii); linking the area of the former industrial complex with the surrounding urban area (iii).

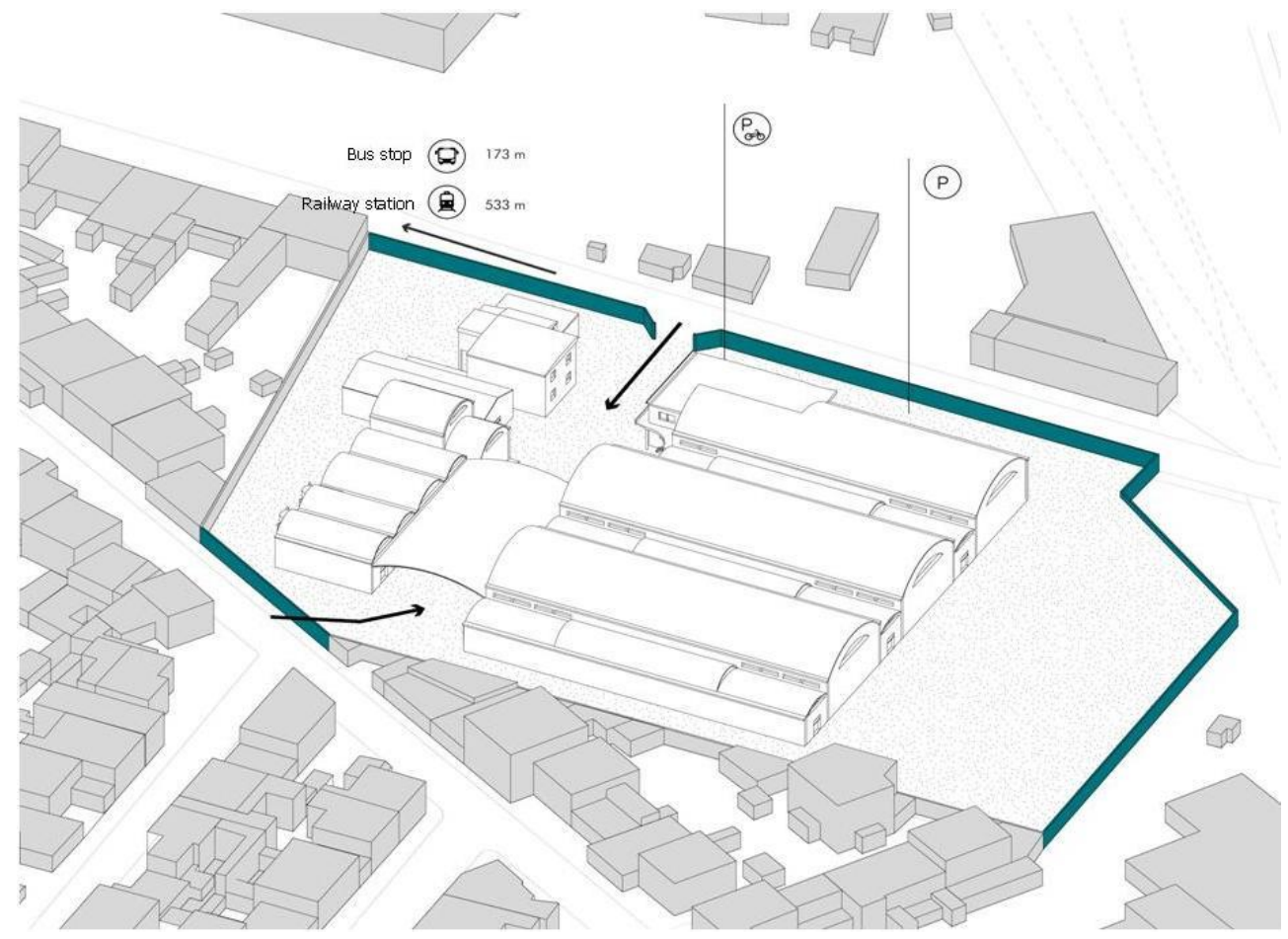

Figure 3. New urban relationships (in green the wall to be demolished). 


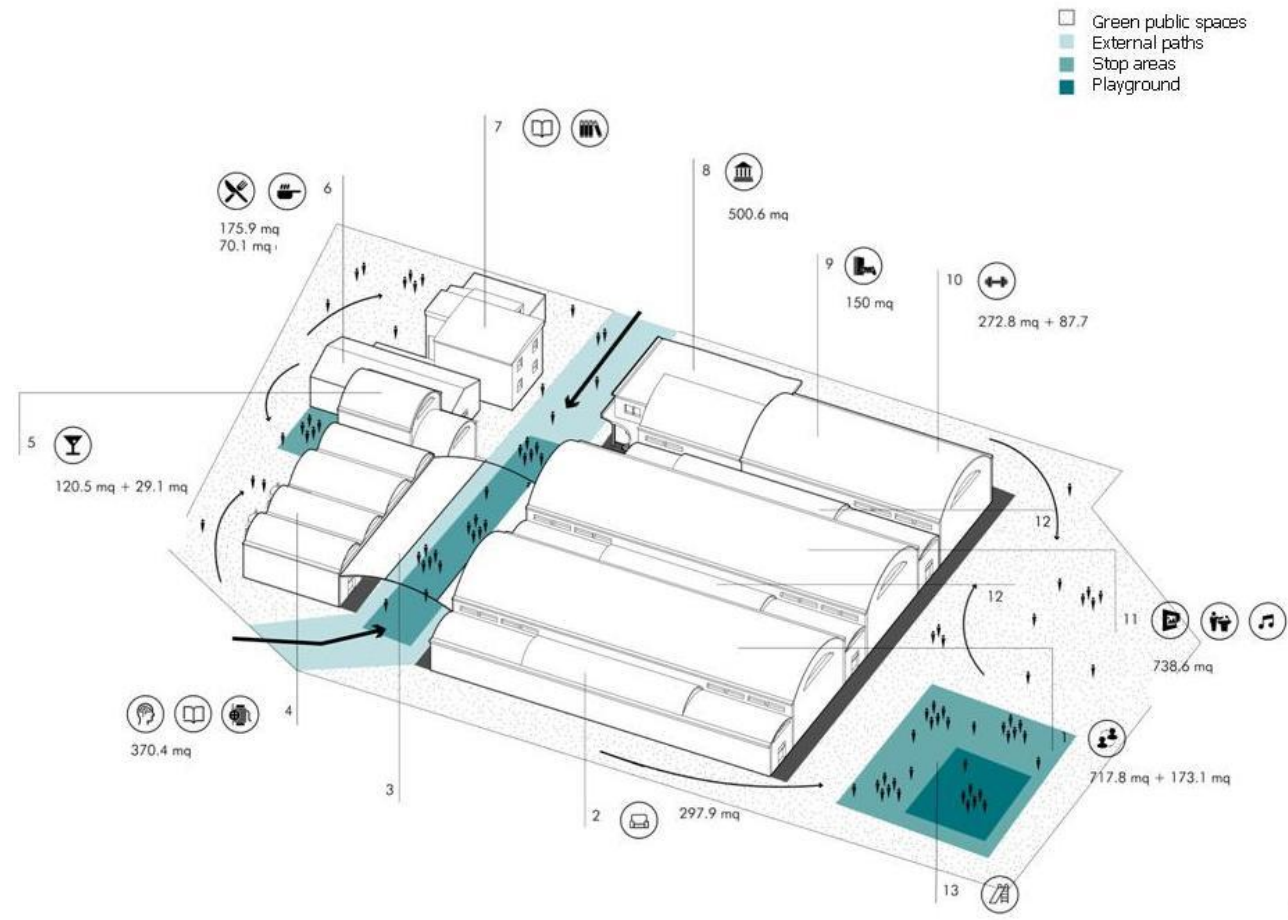

Figure 4. New general functions and external areas.

\subsection{Analysis of Building Materials and Construction Systems}

The analysis of the building systems and the materials used to construct the building allowed us to define the remaining performance of the technical elements. This analysis is the basis for the performance-based design approach to meet the new use requirements. Two main building systems can be observed in the building complex. The first is that used in the rice processing and storage warehouse (Figure $5 b, c$ ), with a rectangular reinforced concrete frame structure and vertical masonry infills made of concrete blocks. Both the roofs of the larger sheds for storing rice (50 $\mathrm{m}$ long and $16 \mathrm{~m}$ wide) and those for processing ( $15 \mathrm{~m}$ long and $7 \mathrm{~m}$ wide) are built with a rounded vaulted ceiling, made of brick-cement (Figure 5c), with an external covering made of asbestos cement slabs. The second is that of the office and accommodation buildings (Figures 2 and $5 \mathrm{a}$ in dark green), with a more regular shape, made of a reinforced concrete framed structure and two floors above ground, with walls of concrete blocks and horizontal slabs of hollow floor blocks and reinforced concrete rafters. The storage and processing rice warehouses are lit from above by simple horizontal iron and glass window systems, placed lengthwise or at the head of the sheds (Figure $5 b, c$ ).

Based on the analysis of the construction systems, two more recent buildings were identified as follows: (1) the connection shed added in 1971 between the storages and the rice processing warehouses (Figure 2 light blue and Figure $5 \mathrm{c}$ ), made of iron-framed load-bearing structure and roofing frame on lowered arch girders, with iron tie rods as bracing and a secondary iron tubular frame (1 mt center-to-center distance), covered with corrugated asbestos cement sheets; (2) the new warehouse added in 1971 between the gatehouse and the pre-existing rice warehouses, built with a reinforced concrete framed load-bearing structure and vertical-cavity walls in concrete blocks (Figure 2 light blue and Figure 5d). The roof of the latter building is made of iron reticular beams combined with iron chains to counteract horizontal forces; the roof covering is made of asbestos cement sheets. 


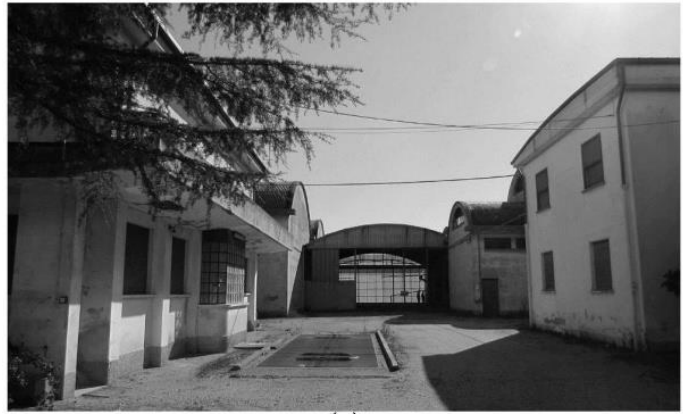

(a)

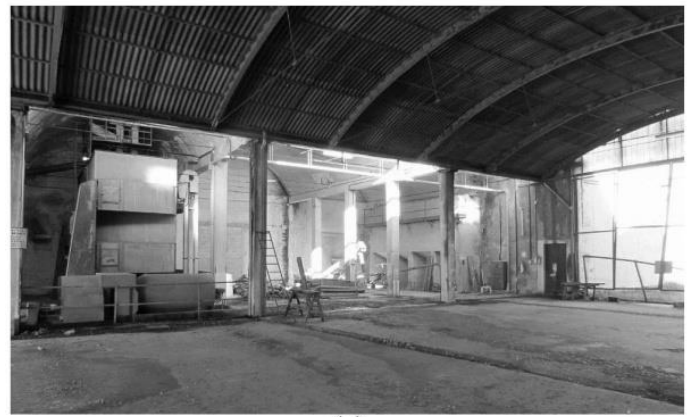

(c)

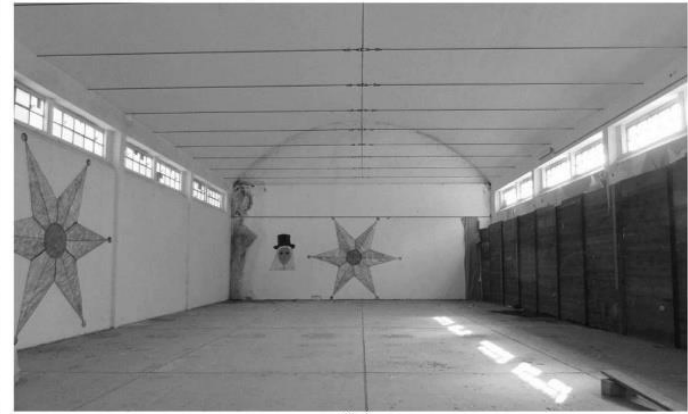

(b)

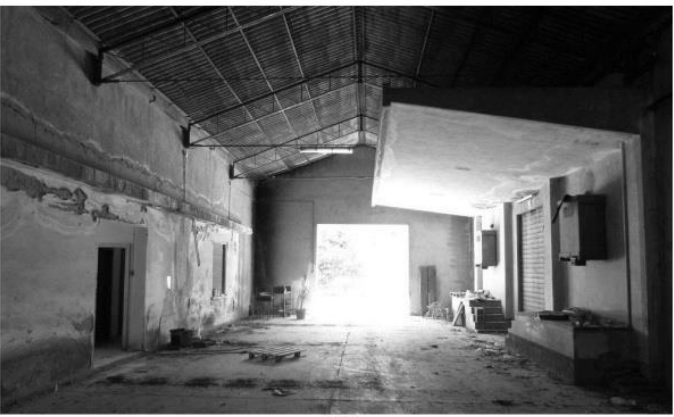

(d)

Figure 5. Distribution space among warehouse, office buildings, and gatehouse (a); natural lighting system in the rice processing warehouses (b); shed added in 1971 and its rounded vaulted ceiling and the background the main storage warehouse (c); new warehouse added in 1971 (d).

In addition, a preliminary visual analysis was carried out to assess both the residual strength of the existing load-bearing structure (reinforced concrete columns and beams) and the decay of the envelope (vertical masonry, base, and roof slabs), as shown in Figure 6. Obviously, a numerical structural verification would be indispensable in order to verify the real remaining structural strength. Nevertheless, the absence of any evident structural instability of the reinforced concrete (oxidation of the reinforcement bars, cracks, or expulsion of the concrete) leads to hypotheses that the load-bearing structures of the bases, columns, and beams are still resistant, as well as the system of concrete low arch beams and metal braces.
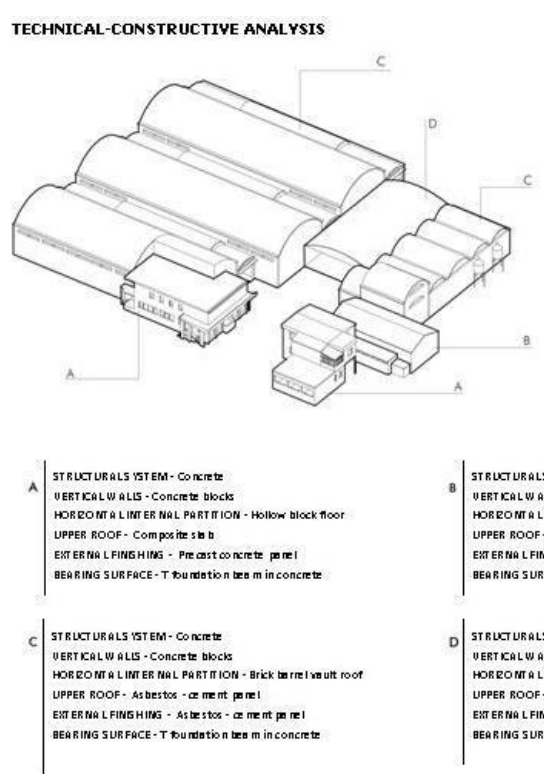

DECAYS ANALYSIS

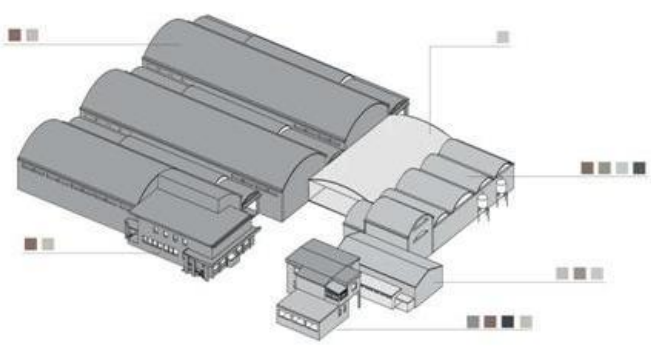

DEcaYs

Rising damp

Plaster detaching

Molds

- Superficial damage

Concrete detaching

II Oxidation

Organic material deposit

Figure 6. Technical constructive analysis (left side); decays analysis (right side). 
The vertical walls made of concrete blocks ( $25 \mathrm{~cm}$ thick) have a thermal transmittance value $\left(2.53 \mathrm{~W} /\left(\mathrm{m}^{2} \cdot \mathrm{K}\right)\right)$ much lower than the required values $\left(0.36 \mathrm{~W} /\left(\mathrm{m}^{2} \cdot \mathrm{K}\right)\right)$; the asbestoscement roofing slabs are of no influence on the thermal insulation performance and should, in any case, be disposed of as they because they are seriously harmful to health and therefore forbidden in Italy by Law 257/1992. The base floors, which are also part of the building envelope, are generally raised off the ground and made of concrete slabs $(160 \mathrm{~cm})$, cement and sand mortar substrate $(60 \mathrm{~mm})$; while concrete structural screed $(100 \mathrm{~mm})$ and limestone rock substrate $(400 \mathrm{~mm})$ are under other base slabs. Considering only the first type, they have a thermal transmittance $\left(1.59 \mathrm{~W} /\left(\mathrm{m}^{2} \cdot \mathrm{K}\right)\right)$ much lower than the required standard value $\left(0.38 \mathrm{~W} /\left(\mathrm{m}^{2} \cdot \mathrm{K}\right)\right)$.

\section{Results and Discussion: Enhancing the Value of Materials and Energy Embedded in Buildings}

The adaptive reuse project of the former industrial complex of the Ente Nazionale Risi in Oristano is based on the selection of new uses and the layout designed to meet the needs of the inhabitants, thus overcoming the weaknesses revealed by the analysis of the urban area. The project aims to optimize the use of space, involving both the large areas of the warehouses for processing and storing rice as well as the connecting galleries, and the smaller office and accommodation buildings. The available buildings are reused according to their size and construction characteristics to include the new functions while minimizing transformation, i.e., demolition and reconstruction, to reduce waste production and optimize the remaining technological performance.

According to the scheme in Figures 7-9, the layout includes a co-working area (1) and lounge (2); a covered public space (3); an atelier (4); reading rooms (5); a restaurant (6); study rooms (7); rice museum (8); gymnasium and playground (9a and 9b); exhibition hall (11). It is planned to remove the original perimeter wall to extend the outdoor space (as shown in Figures 3 and 4), transforming it into a green park and a playground open to the city (12).

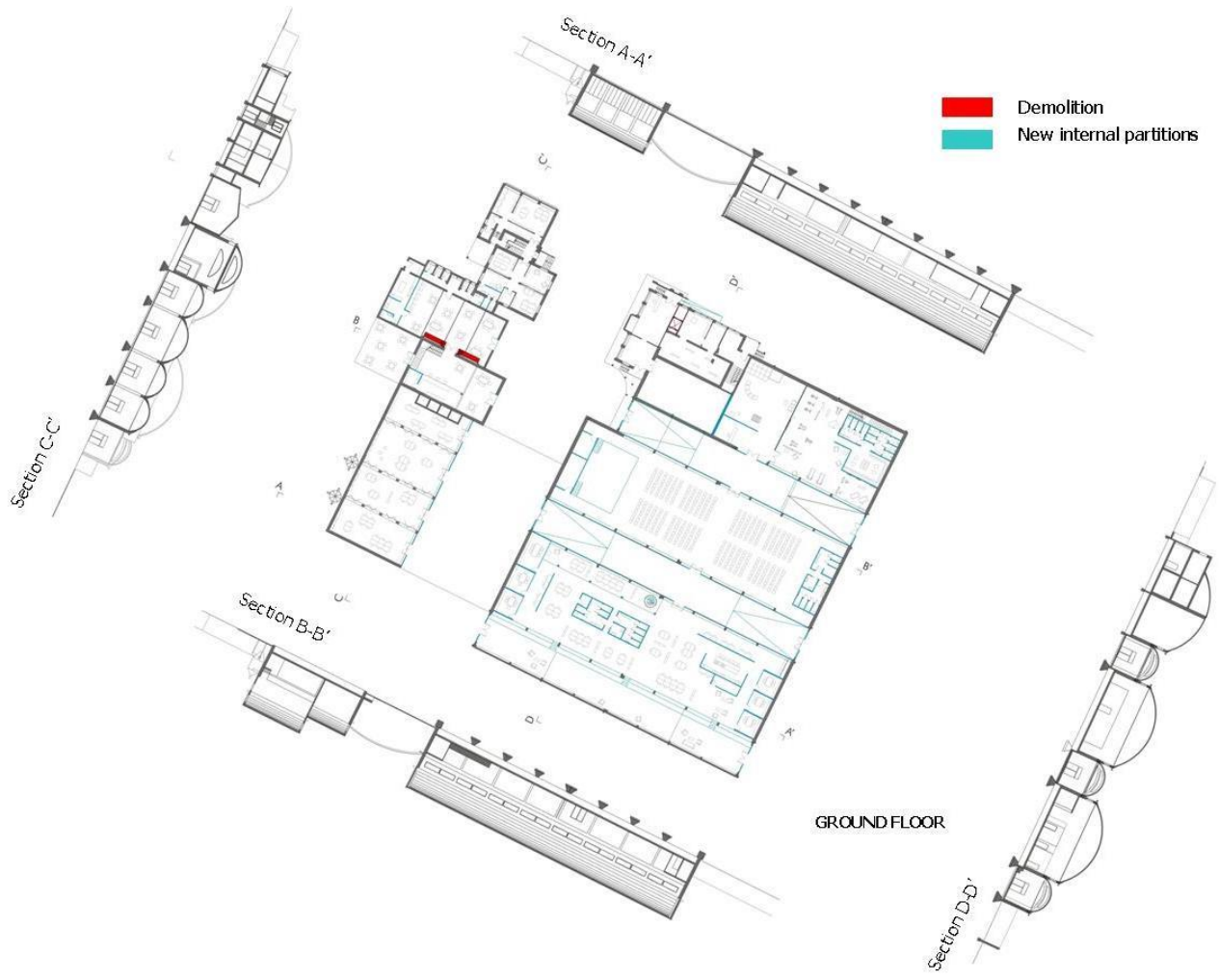

Figure 7. Plan and sections: adaptive reuse proposal (in green lightweight modular partition walls). 


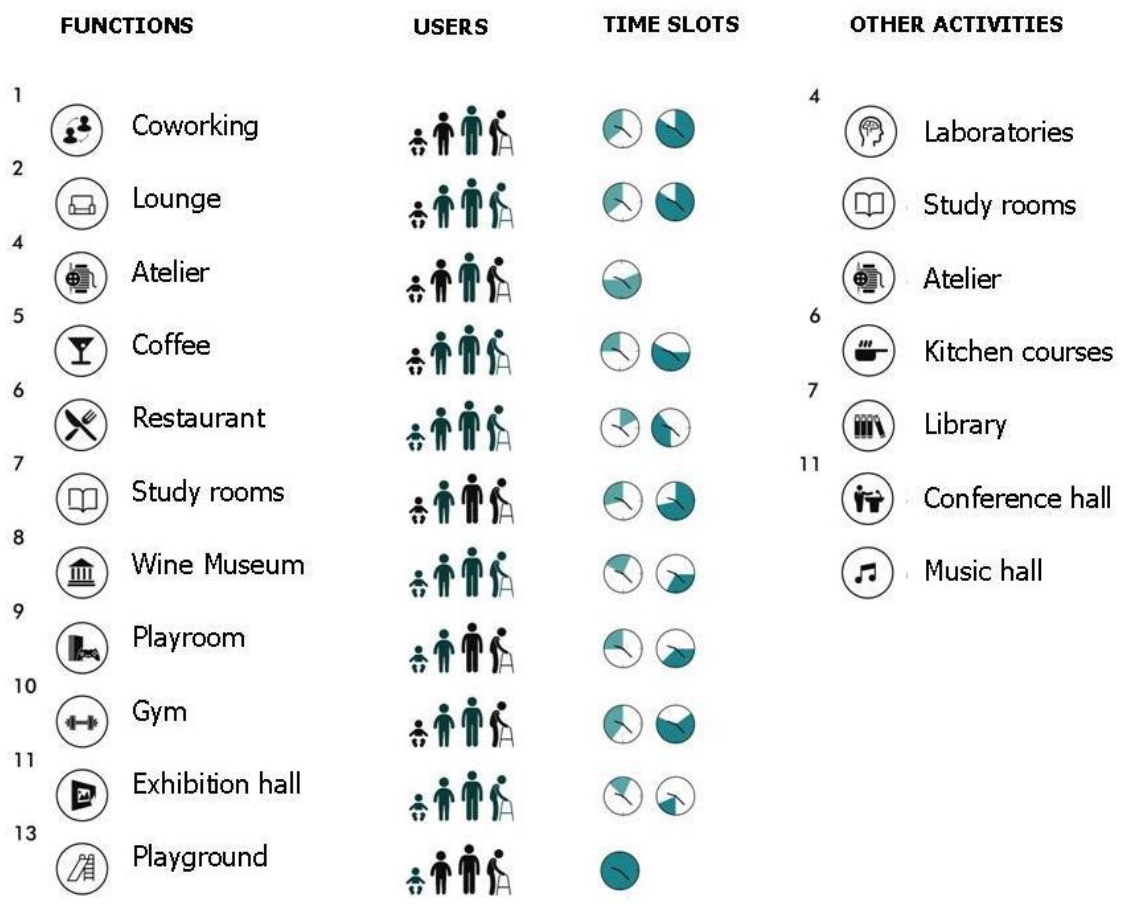

Figure 8. New functions and further activities in relationship whit the user's needs.

The project takes into account the possible use variations through movable walls in wood or metal, which allow the transformation and adaptation of the layout: atelier can be converted in educational laboratories; study rooms can be converted in the diffused library; exhibition hall can be converted in a conference room or concert hall as showed in Figures 7-9). This approach, on the one hand, pursues the flexibility of the indoor spaces and, on the other hand, allows their adaptation over the years, avoiding burdensome adaptation works and contributing to the reduction of construction and demolition waste. Therefore, the flexibility of use leads to a longer life cycle of buildings.

The adaptation of the former Ente Nazionale Risi compound involves the retrofitting of both the structural system and the building envelope to guarantee safety and comfort for the users. The new functions concern, in particular, the warehouses for storing and processing rice, buildings with only one floor above ground, without intermediate floors; while the office buildings have been earmarked for functions similar to the original ones, thus implicitly guaranteeing residual structural reliability., In addition, as recognized in the literature, improving the thermal insulation of the building envelope is an essential objective in the rehabilitation of the building stock, in order to contribute to the reduction of greenhouse gases. Therefore, the research focused on the performance adaptation of the envelope for the methodology implementation, only considering the thermal insulation requirements. In this sense, according to the literature, we have considered the external vertical walls, the roofs, and the base floors as part of the dispersing building envelope.

As a preliminary step, the material degradation of the building envelope of the whole group of buildings has been mapped, for calculating the amount of material to be removed, as it is no longer compliant with regulations (asbestos cement roofing and fixtures), as it is degraded (plasters) or as it is dangerous for the users (in particular structural elements: beams, columns or floors). The demolition of some internal and external walls (connecting shed) made of concrete blocks has however been hypothesized to improve the flexibility of use and circulation especially in the outdoor areas among buildings and the urban surrounding. 


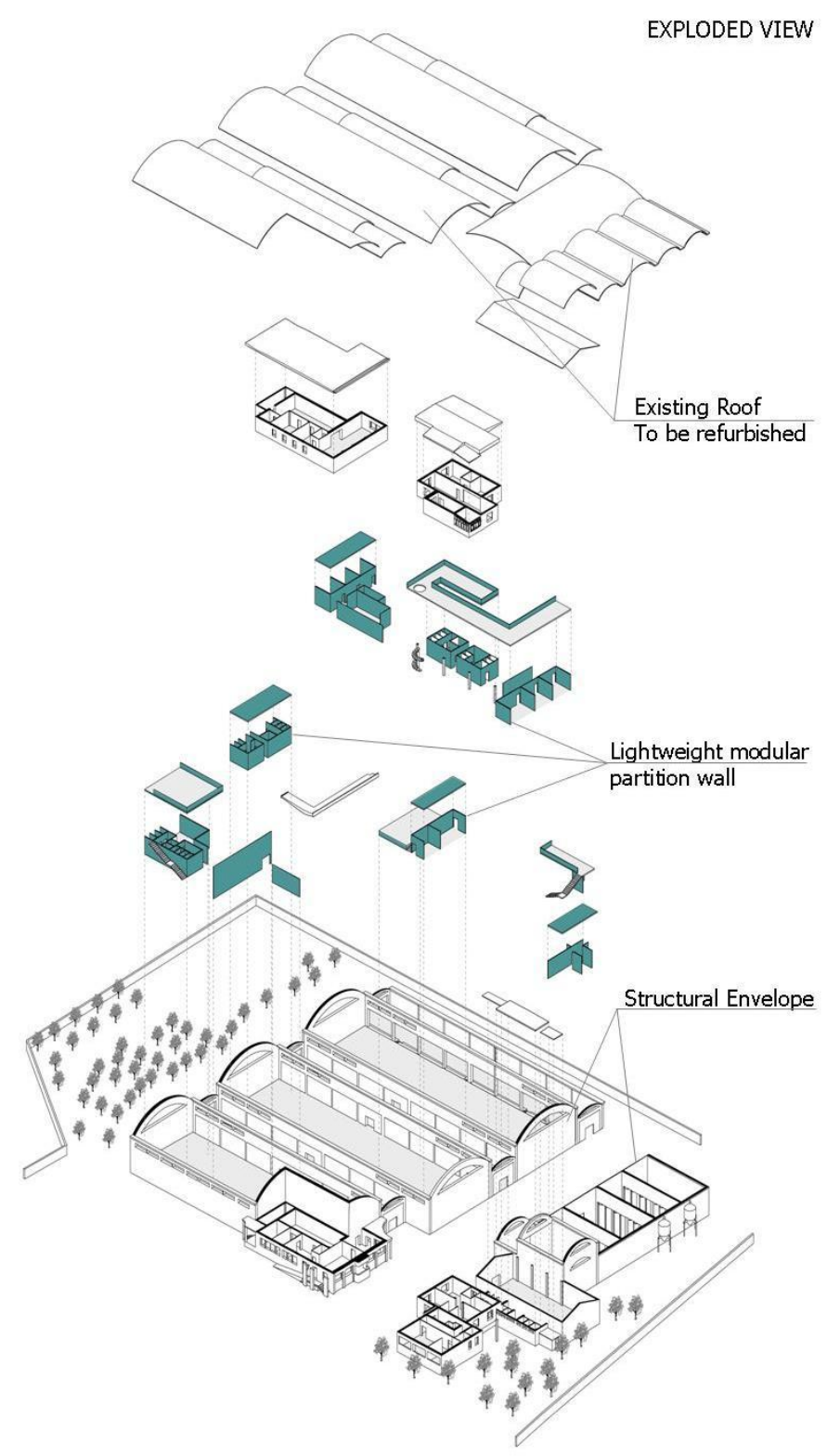

Figure 9. Axonometric view (in green modular partition walls to adapt the spaces).

Subsequently, using the $\mathrm{EE}$ and $\mathrm{EC}$ values expressed in $\mathrm{MJ} / \mathrm{kg}$ and $\mathrm{kgCO}_{2} \mathrm{eq} / \mathrm{kg}$ of product (from the Inventory Carbon and Energy, rel 3.0) [67,68], we considered one square meter as the functional unit and the total amount of embodied energy $\left(\mathrm{EE}_{\mathrm{bm}}\right.$ and $\left.\mathrm{EC}_{\mathrm{bm}}\right)$ in each building element of the building envelope-basement floors, external walls, and roofs-has been calculated. Furthermore, the waste energy (expressed in MJ $/ \mathrm{kg}$ ) due to demolition has been identified to highlight the energy lost along with the materials landfilling. Regardless of the new use, the required thermal insulation performance levels of the building envelope have been established, the residual performance efficiency of each building element has been calculated and a first environmental profile of the building has been defined.

By separating the materials to be disposed of from those that could be downcycled or upcycled (plasters and reinforced concrete structural elements, concrete blocks of the perimeter wall, pavements in concrete), the amounts of recoverable material and energy $\left(\mathrm{EE}_{\text {down }}\right.$ and $\left.\mathrm{EE}_{\mathrm{up}}\right)$ have been calculated; the related amount of carbon energy recovered represents the share of GHG emissions saved. The results have been summarised through a detailed technical analysis of each building element, distinguishing the materials of each functional layer, and assigning to each a specific intervention among preservation, 
recovery/reuse, recycling, or disposal. This allows the objectives of downcycling and upcycling — valorizing matter and energy — associated with the retrofit project to be pursued and contributes positively to the overall environmental balance of the intervention.

Based on the thermal transmittance values of the building envelope required by current regulations, two technological alternatives have been evaluated for the following building elements: base slabs, vertical walls, and pavilion roofs; while we have neglected the external window frames because they will have to be replaced due to their irreversible technological obsolescence and advanced decay status.

\subsection{Base Slabs}

The current thermal transmittance value is $1.44 \mathrm{~W} /\left(\mathrm{m}^{2} \cdot \mathrm{K}\right)$, obtained applying the current formula from literature thus constituting $26 \%$ of the required performance. In order to reach the standard values, it is necessary to remove the concrete floor and screed to add an insulating layer; then the screed (50\% downcycling) and the floor (100\% upcycling) are reinstalled. The first design alternative (i) involves the use of a high-density polystyrene panel $(7 \mathrm{~cm})$, on top of which a new lightweight concrete screed is made and the recovered floor is installed. In the second case (ii), the insulation layer is replaced with a cork panel $(9 \mathrm{~cm})$. Considering the original embodied energy $(615.84 \mathrm{MJ} / \mathrm{kg})$, the use of the polystyrene panel results in an increase of $76.75 \%$ in Embodied Energy and an increase in $\mathrm{CO}_{2}$ emissions of $24.91 \%$, while the solution using the cork panel results in an increase in $\mathrm{EE}$ of $6.45 \%$ and $\mathrm{CO}_{2}$ emissions of $3.3 \%$. Nonetheless, considering the possibility of conserving and reusing the structural part of the concrete slab, we will have a saving in unspent energy of $525.60 \mathrm{MJ} / \mathrm{kg}$ and $46.06 \mathrm{CO}_{2} \mathrm{equ} / \mathrm{Kg}$. In this case, it is further possible to recycle the screed as a substrate in other processes as shown in Figure 10.

\begin{tabular}{|c|c|c|c|c|c|c|c|c|c|c|}
\hline Ground Floor Slab (GFS) & & Layers/Materials & $\begin{array}{l}\text { Dimension/Thi } \\
\text { ckness (cm) }\end{array}$ & $\begin{array}{l}\text { Density } \\
\left(\mathrm{kg} / \mathrm{m}^{3}\right)\end{array}$ & $\begin{array}{c}\text { Functional } \\
\text { Unity value } \\
\left(\mathrm{kg} / \mathrm{m}^{2}\right)\end{array}$ & $\begin{array}{c}E . E \\
(\mathrm{MJ} / \mathrm{Kg})\end{array}$ & $\begin{array}{c}\begin{array}{c}E . E . \\
\left(\mathrm{M} / \mathrm{m}^{2}\right)\end{array} \\
\end{array}$ & $\begin{array}{l}\text { E.Carbon } \\
\text { (KgCOC2 } \\
\text { eq/Kg) }\end{array}$ & $\begin{array}{c}\text { Total } \\
(\mathrm{kgcO} C \mathrm{Ceq} / \\
\left.\mathrm{m}^{2}\right)\end{array}$ & Action \\
\hline \multirow{4}{*}{$\frac{\left.\left.\right|^{3}\right|^{4}}{{ }_{2}{ }_{1} \mid}$} & 4 & Cement floor & 3.00 & $1,200.00$ & 36.00 & 1.24 & 44.64 & 0.13 & 4.57 & $\begin{array}{l}\text { Diasssembling } \\
\text { Reuse (100\%) }\end{array}$ \\
\hline & 3 & $\begin{array}{c}\begin{array}{c}\text { base course } \\
\text { (concrete) }\end{array} \\
\end{array}$ & 3.00 & $1,600.00$ & 48.00 & 0.95 & 45.60 & 0.13 & 6.24 & $\begin{array}{c}\text { Disassembling } \\
\text { Reuse(50\%) }\end{array}$ \\
\hline & 2 & Concrete topping & 6.00 & $1,600.00$ & 96.00 & 1.10 & 105.60 & 0.16 & 15.26 & Preservation \\
\hline & 1 & hollow block floor & 16.00 & 1,500.00 & 140.00 & 3.00 & 420.00 & 0.22 & 30.80 & Preservation \\
\hline $\mathbf{a}$ & & $\begin{array}{l}\text { Thermal trasmitta } \\
\text { Performance effic }\end{array}$ & $\begin{array}{l}\text { ance }(U)= \\
\text { acy }=\end{array}$ & $\begin{array}{l}1.46 \mathrm{~W} / \mathrm{m}^{2} \mathrm{~K} \\
26 \%\end{array}$ & & & 615.84 & & $\begin{array}{c}56.88 \\
\end{array}$ & \\
\hline
\end{tabular}

\begin{tabular}{|c|c|c|c|c|c|c|c|c|c|c|}
\hline Ground Floor Slab (GFS) & Layers/Material & $\begin{array}{l}\text { Dimension/Thi } \\
\text { ekness }(\mathrm{cm})\end{array}$ & $\begin{array}{l}\text { Density } \\
\left(\mathrm{kg} / \mathrm{m}^{3}\right)\end{array}$ & $\begin{array}{c}\begin{array}{c}\text { Functional } \\
\text { Unity Value } \\
\left(\mathrm{kg}^{2} / \mathrm{m}^{2}\right)\end{array} \\
\end{array}$ & $\begin{array}{c}\begin{array}{c}E . E \\
(\mathrm{MJ} / \mathrm{Kg})\end{array} \\
\end{array}$ & $\begin{array}{c}E . E . \\
\left(\mathrm{MJ} / \mathrm{m}^{2}\right)\end{array}$ & $\begin{array}{r}\text { E.Carbon } \\
\text { (KgCO22 } \\
\text { eq/Kg) } \\
\end{array}$ & $\begin{array}{c}\text { Total } \\
(\mathrm{kggCozeq} / \\
\left.\mathrm{m}^{2}\right)\end{array}$ & $\begin{array}{c}\text { Thermal } \\
\text { Conductivity } \lambda \\
(\text { W/mK })\end{array}$ & SOURCE \\
\hline \multirow{7}{*}{$\frac{6}{3}$} & $\begin{array}{c}\text { Cement floor } \\
\text { (REUSE) }\end{array}$ & 3.00 & $1,200.00$ & 36.00 & 1.24 & 44.64 & 0.13 & 4.57 & 1.40 & $100 \%$ reused \\
\hline & $\begin{array}{l}\text { base course } \\
\text { (concrete) }\end{array}$ & 3.00 & $1,600.00$ & 48.00 & 0.95 & 45.60 & 0.13 & 6.24 & 1.60 & $50 \%$ upcycled \\
\hline & $\begin{array}{c}\text { Insulation } \\
\text { (polystyrene) }\end{array}$ & 7.00 & 33.00 & 2.31 & 88.60 & 204.67 & 2.50 & 5.78 & 0.04 & NEW \\
\hline & $3 \quad \begin{array}{c}\text { damp-proof } \\
\text { membrane }\end{array}$ & 0.20 & $1,000.00$ & 2.00 & 134.00 & 268.00 & 4.20 & 8.40 & 0.15 & NEW \\
\hline & Concrete topping & 6.00 & $1,600.00$ & 96.00 & 1.10 & 105.60 & 0.16 & 15.26 & 0.45 & Preserved \\
\hline & 1 hollow block floor & 16.00 & $1,500.00$ & 140.00 & 3.00 & $\begin{array}{l}420.00 \\
\end{array}$ & 0.22 & 30.80 & 0.80 & Preserved \\
\hline & & & & & & $1,088.51$ & & 71.05 & & \\
\hline
\end{tabular}

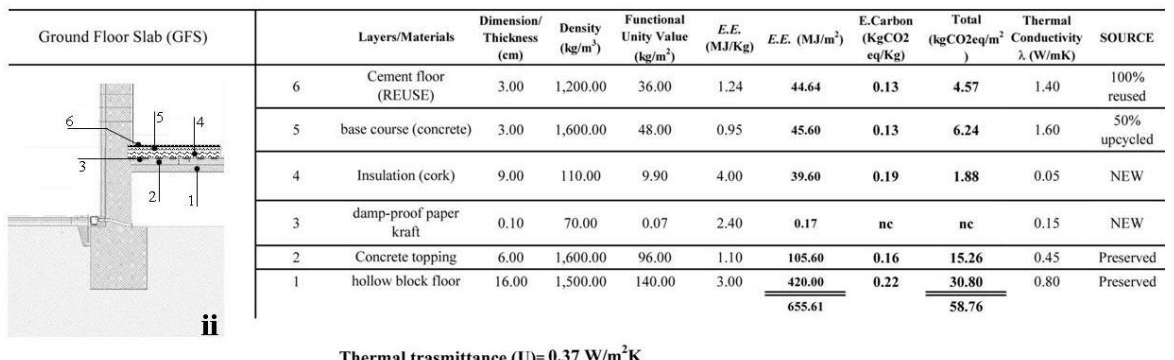

Figure 10. Ground floor slab: current status (a); design alternative (i); design alternative (ii). 


\subsection{Vertical External Walls}

The current thermal transmittance value is $2.273 \mathrm{~W} /\left(\mathrm{m}^{2} \cdot \mathrm{K}\right)$, i.e., $15.83 \%$ of the required performance. The two alternatives considered involve (i) the construction of external cladding in rigid extruded expanded polystyrene panels with graphite, (ii) the construction of an internal cladding with cork panels and air cavity, and a plasterboard finish. The second solution (ii) also allows to place the ducts systems of the new plants in the cavity, avoiding the in-wall installation, thus contributing to the reduction of construction works and the overall production of construction and demolition waste. In solution (i) there is an overall increase of $27.45 \%$ of $\mathrm{EE}$ and $1.85 \%$ of $\mathrm{CO}_{2} \mathrm{equ}$, while in solution (ii) there is an increase of $23.76 \%$ of $\mathrm{EE}$ and $5.68 \%$ of $\mathrm{CO}_{2} \mathrm{equ}$; however, in both cases, $30 \%$ of the external and internal plastering is demolished and $70 \%$ is conserved with punctual repairs and maintenance of the external walls, saving $480.4 \mathrm{MJ}$ of EE and $52.38 \mathrm{CO}_{2}$ equ of EC per square meter of the envelope. In case (ii) the higher percentage increase of $\mathrm{CO}_{2} \mathrm{equ}$ will be largely compensated by the location of duct systems in the cavity between the walls and the finishing panels, resulting in reduced emissions associated with further avoided demolition for the installation of technological systems as shown in Figure 11.

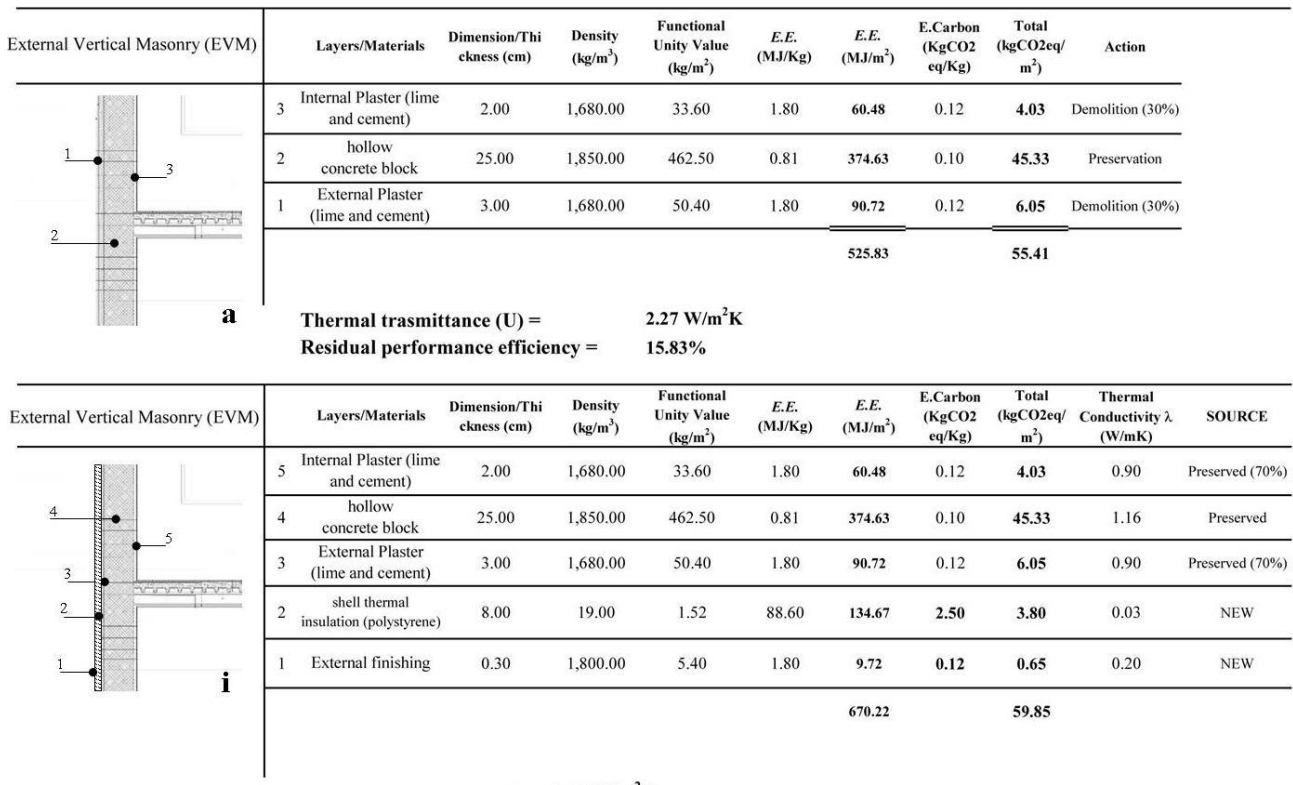

Thermal trasmittance $(U)=0.34 \mathrm{~W} / \mathrm{m}^{2} \mathrm{~K}$

\begin{tabular}{|c|c|c|c|c|c|c|c|c|c|c|c|}
\hline External Vertical Masonry (EVM) & & Layers/Materials & $\underset{\text { ichnes }}{\text { Dimens }}$ Ex & rnal Vertica & $\begin{array}{l}\text { Functional } \\
\text { Masonry (EVM }\end{array}$ & $\begin{array}{l}E \\
\text { M) } / \mathrm{Kg} \text { ) }\end{array}$ & E.E. $\left(\mathrm{MJ} / \mathrm{m}^{2}\right)$ & $\begin{array}{c}\text { E.Carbon } \\
(\mathrm{KggC2} \\
\mathrm{eq} / \mathrm{Kg}) \\
\end{array}$ & $\begin{array}{c}\text { Total } \\
\left(\mathrm{kgCO2eq} / \mathrm{m}^{2}\right. \\
1 \\
\end{array}$ & $\begin{array}{c}\text { Thermal } \\
\text { Conductivity } \lambda \\
(\mathbf{W} / \mathbf{m K}) \\
\end{array}$ & SOURCE \\
\hline & 7 & Plaster Gypsum & 0.20 & $1,120.00$ & 2.24 & 1.80 & 4.03 & 0.12 & 0.27 & 0.20 & NEW \\
\hline & 6 & plasterboard & 1.20 & 950.00 & 11.40 & 6.75 & 76.95 & 0.38 & 4.33 & 0.21 & NEW \\
\hline 4 & 5 & Air & 3.00 & 0.00 & 0.00 & 0.00 & 0.00 & 0.00 & 0.00 & 0.14 & - \\
\hline - & 4 & Insulation (Cork Panel) & 10.00 & 110.00 & 11.00 & 4.00 & 44.00 & 0.19 & 2.09 & 0.05 & NEW \\
\hline \multirow{3}{*}{ 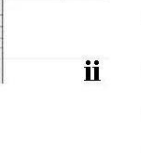 } & 3 & $\begin{array}{c}\text { Intemal Plaster (lime } \\
\text { and cement) }\end{array}$ & 2.00 & $1,680.00$ & 33.60 & 1.80 & 60.48 & 0.12 & 4.03 & 0.90 & Preserved \\
\hline & 2 & $\begin{array}{c}\text { hollow } \\
\text { concrete block }\end{array}$ & 25.00 & $1,850.00$ & 462.50 & 0.81 & 374.63 & 0.10 & 45.33 & 1.16 & Preserved \\
\hline & 1 & $\begin{array}{l}\text { External Plaster (lime } \\
\text { and cement) }\end{array}$ & 3.00 & $1,680.00$ & 50.40 & 1.80 & 90.72 & 0.12 & 6.05 & 0.90 & Preserved \\
\hline
\end{tabular}

Thermal trasmittance $(\mathrm{U})=0.34 \mathrm{~W} / \mathrm{m}^{2} \mathrm{~K}$

Figure 11. External vertical masonry: current status (a); with external insulation (i); with internal insulation (ii).

\subsection{Dropped Barrel Vaults of the Sheds}

The current thermal transmittance value of the roof is $1.70 \mathrm{~W} /\left(\mathrm{m}^{2} \cdot \mathrm{K}\right)$, equal to $18.82 \%$ remaining performance. The first of the two alternatives examined consists in the dismantling and disposal of the corrugated fiber-cement roofing (i), while the second provides for its encapsulation (ii) through the overlapping of a lightweight screed made of concrete and 
$4 \mathrm{~cm}$ expanded perlite. In both cases, the vaulted roof structure is maintained, providing for reuse through upcycling (i.e., implementation of thermal insulation of the building element). For both cases, $460.40 \mathrm{MJ}$ of $\mathrm{EE}$ and $38.78 \mathrm{CO}_{2}$ equiv. of EC per $\mathrm{m}^{2}$ are saved. To improve the thermal performance of the roof, an air cavity has been considered in the two alternatives to facilitate heat dissipation (in summer), since the area is highly sunny. In solution (i), from the original value of $\mathrm{EE}\left(571.40 \mathrm{MJ} / \mathrm{m}^{2}\right)$ and $\mathrm{EC}\left(38.78 \mathrm{CO}_{2} \mathrm{equ} / \mathrm{m}^{2}\right)$, an increase of $108.57 \%$ in $\mathrm{EE}$ and $120.34 \%$ in EC is obtained. In solution (ii), EE increases by $162.98 \%$ while EC increases by $140.22 \%$. These values are due to the need to reconstruct almost the entire roof, excluding the dropped hollow slab vault (Figure 12). Furthermore, the higher EE and EC increase of the second solution is due to the decision to maintain and encapsulate the fiber cement roof as well, despite the fact that the calculation of the related energy expenditure has been omitted.

\begin{tabular}{|c|c|c|c|c|c|c|c|c|c|c|}
\hline Barrel Vault Roof (BVR) & Layers/Materials & $\begin{array}{l}\text { Dimension/Thi } \\
\text { ckness (em) }\end{array}$ & $\begin{array}{l}\text { Density } \\
\left(\mathrm{kg} / \mathrm{m}^{3}\right)\end{array}$ & $\begin{array}{c}\begin{array}{c}\text { Functional } \\
\text { Unity value } \\
\left(\mathrm{kg} / \mathrm{m}^{2}\right)\end{array} \\
\end{array}$ & 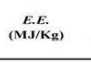 & $\underset{\left(M \cdot E / m^{2}\right)}{E E}$ & $\begin{array}{c}\text { E.Carbon } \\
\text { (KgCO2 } \\
\text { eq/Kg) }\end{array}$ & $\begin{array}{c}\text { Total } \\
\left(\begin{array}{c}\text { (KgCOzeq } / \\
\left.\text { men }^{2}\right)\end{array}\right.\end{array}$ & Action & \\
\hline \multirow{4}{*}{3} & 3 Corrugated asbestos- & Var & $1,625.00$ & 15.00 & 7.40 & 111.00 & N.C & ENC & $\begin{array}{l}\text { DISPOSALI } \\
\text { NCAPSULATION }\end{array}$ & \\
\hline & Concrete topping & 4.00 & 1.600 .00 & 64.00 & 1.10 & 70.40 & 0.16 & 10.18 & Preservation & \\
\hline & $1 \quad \begin{array}{c}\text { arch roof (hollow } \\
\text { floor brick) }\end{array}$ & 16.00 & $1,120.00$ & 130.00 & 3.00 & 390.00 & 0.22 & 28.60 & Preservation & \\
\hline & \multirow{2}{*}{\multicolumn{3}{|c|}{$\begin{array}{l}\text { Thermal trasmittance }(\mathrm{U})= \\
\text { Residual performance efficiency }=\end{array}$}} & \multirow{2}{*}{\multicolumn{2}{|c|}{$\begin{array}{l}1.70 \mathrm{~W} / \mathrm{m}^{2} \mathrm{~K} \\
18.82 \%\end{array}$}} & 571.40 & & 38.78 & & \\
\hline a & & & & & & & & & & \\
\hline Barrel Vault Roof (BVR) & Layers/Materials & $\begin{array}{l}\text { Dimension/Thi } \\
\text { ckness (cm) }\end{array}$ & $\begin{array}{l}\text { Density } \\
\left(\mathbf{k g} / \mathbf{m}^{3}\right)\end{array}$ & $\begin{array}{l}\text { Functional } \\
\text { Unity Value } \\
\left(\mathrm{kg} / \mathrm{m}^{2}\right)\end{array}$ & $\begin{array}{l}E, E . \\
(\mathbf{M} / / K \underline{K})\end{array}$ & $\begin{array}{c}E \cdot E . \\
\left(M \cdot J / \mathbf{m}^{2}\right)\end{array}$ & $\begin{array}{l}\text { E.Carbon } \\
\text { (KgCO2 } \\
\text { Kq } / \mathbf{K g})\end{array}$ & 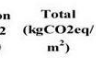 & $\begin{array}{c}\text { Thermal } \\
q^{\prime} \quad \begin{array}{c}\text { Thenctivity } \lambda \\
\text { (W/mK) }\end{array}\end{array}$ & SOURCE \\
\hline \multirow[b]{5}{*}{ 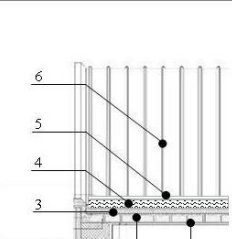 } & $8 \begin{array}{c}\text { corrugated } \\
\text { Galvanized Steel } \\
\text { Sheet }\end{array}$ & 0.18 & var & 14.13 & 39.00 & 551.07 & 2.82 & 39.85 & 17.00 & NEW \\
\hline & Air & 3.00 & 0.00 & 0.00 & 0.00 & 0.00 & 0.00 & 0.00 & 0.14 & - \\
\hline & Polyethilene sheet & 0.16 & 940.00 & 1.50 & 78.10 & 117.46 & 1.70 & 2.56 & 0.15 & NEW \\
\hline & $5 \quad \begin{array}{c}\text { shell thermal } \\
\text { insulation } \\
\text { (rockwool) }\end{array}$ & 10.00 & 55.00 & 5.50 & 16.80 & 92.40 & 1.05 & 5.78 & 0.03 & NEW \\
\hline & $4 \quad \begin{array}{c}\text { Concrete topping } \\
\text { (light expanded } \\
\text { elay) }\end{array}$ & 4.00 & 500.00 & 20.00 & 11.80 & 236.00 & 0.16 & 3.18 & 0.17 & NEW \\
\hline \multirow{3}{*}{ i } & 3 Concrete topping & 4.00 & $1,600.00$ & 64.00 & 1.10 & 70.40 & 0.16 & 10.18 & 0.30 & Preserved \\
\hline & $2 \quad \begin{array}{c}\text { arch roof (hollow } \\
\text { floor brick) }\end{array}$ & 16.00 & $1,120.00$ & 130.00 & 3.00 & 390.00 & 0.22 & 28.60 & 0.20 & Preserved \\
\hline & $\begin{array}{l}\text { Internal Plaster (lime } \\
\text { and cement) }\end{array}$ & 1.50 & $1,680.00$ & 25.20 & 1.80 & 45.36 & 0.12 & 3.02 & 0.90 & NEW \\
\hline
\end{tabular}

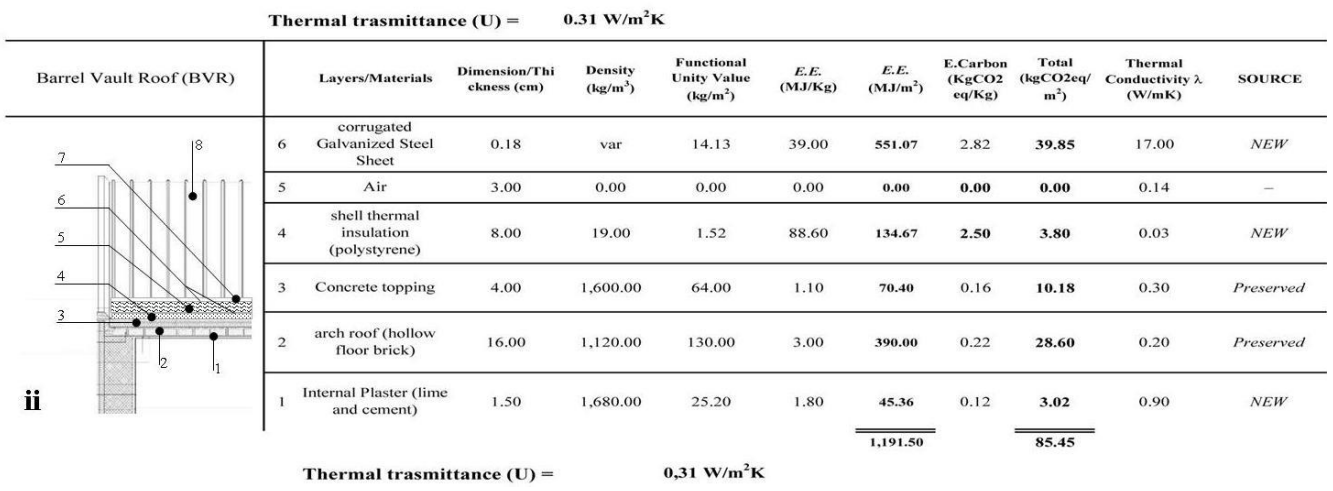

Figure 12. Analysis of building elements: current status (a); with insulation in polystyrene (i); with insulation in rockwool (ii).

The second design alternative for the roofing shows that a reduction of construction and demolition waste (which in this case is as hazardous to health as concrete with asbestos fibers) is not always reflected in a linear decrease in associated environmental impacts.

The research highlights that the rehabilitation project is not always neutral but requires a preliminary careful environmental assessment of the technological alternatives. The environmental data used from the eco-inventory ICE (rel 3.0), allowed an estimation of the impacts associated with the new materials required (negative impacts) that can be balanced 
with the positive ones due to the conservation and reuse, or dismantling and recycling of the existing ones.

However, for a more in-depth and comprehensive analysis of the environmental impacts associated with the project choices, it would be appropriate to extend the assessment considering the whole life cycle of the building [73].

In the design phase, the ranking system thoroughly analyses the retrofitting alternatives related to the building elements, by identifying a corresponding environmental profile and considering the equivalent technological performance, leads to solutions able to enhance the existing material by reducing the input of new material and valorizing embodied energy and already emitted $\mathrm{CO}_{2}$. The impact rates calculated in the different scenarios confirm the initial hypotheses: with the same functional performance achieved post-intervention, keeping in use a greater quantity of materials and components that are still suitable, by extending their life cycle, allows to reduce both the production of demolition waste and the addition of new materials, which have a greater impact on the overall environmental balance. This allows for the upcycling of construction elements, while the selective dismantling and demolition of materials and components deemed unsuitable for reuse implies their downcycling.

This allows us to: keep as many materials as possible in place, by limiting additions and replacements; recycle discarded materials; choose materials on the basis of their environmental profile in accordance with operational criteria that have been recognized in the literature for many years $[74,75]$. The results confirm the environmental convenience of the rehabilitation intervention according to the presented methodology, as it contributes both to the reduction of energy consumption during the construction phase compared to new construction [76] and the consumption of new primary resources. Similarly, the positive contribution of the share of recycled material in the environmental balance with respect to the whole life cycle of the building is confirmed [77]. Finally, even using an expeditious method from an LCA perspective, based on indicators such as the quantities of materials, energy used, and waste produced, that steers choices towards building solutions with less embodied energy, and the results obtained confirm that it is possible to control the environmental impacts produced, and thus contribute, indirectly, to the reduction of their recovery time $[78,79]$.

\section{Conclusions and Future Applications}

The international scientific debate agrees that the renovation of the built environment can lead to a reduction of primary resource use and greenhouse gas emissions as well as a decrease in construction and demolition wastes. According to the scenario outlined in Section 2, a new methodology has been developed and tested to assess the environmental impacts associated with improving the thermal insulation of the building envelope of a former industrial complex, combining the approach based on the circular use of resources with a performance-based approach, and proposing technological solutions based on the downcycling and upcycling of building materials and components. The innovative perspective of the developed methodology concerns the estimation of the embodied energy and $\mathrm{CO}_{2}$ emissions related to the 'from cradle to gate' phase of the building materials starting from the preliminary assessment of the remaining technological performance, which provides an essential knowledge to choose the preferred retrofit intervention, in a perspective of circularity of resources [80]. This allows both the optimization of the materials that are still suitable and the exploitation of their embodied energy [81], reducing the production of construction and demolition waste and leading to the reuse of the quantities that cannot be saved. In addition, the scale of the executive design confirms the reliability of the methodology as a decision-support tool for designers in the most delicate phase of the requalification project, flanking the verification of residual technological performance with the quantification of induced environmental impacts [82].

Nevertheless, such impact depends on many factors and cannot always be easily estimated. If the other phases of the building's life cycle were taken into account, the 
overall balance of environmental impact could change. Moreover, according to a multilevel approach that analyses the building system from the building component to the whole building and its context, in order to preliminarily quantify the environmental balances of retrofitting abandoned built heritage, further research scenarios can be considered.

Indeed, the rehabilitation of the built environment also requires economic evaluations, as the extension of the useful life cycle of a building depends on both the initial decay conditions and the cost of intervention alternatives according to the required performance [83-85]. Starting from the residual performance of the existing building, the LCC analysis would allow the evaluation of energy efficiency alternatives based on the payback period compared to the overall cost as a function of the building life cycle.

Moreover, for the present experimentation, as already mentioned, we left out both the economic issues and the verification of the residual strength of the existing structures as well as other requirements related to the safety of the occupants. The research aims to give evidence of the relationships between the rehabilitation or adaptive reuse design of the built environment and the knowledge of its remaining technological performance, in particular by considering the contribution that this strategy could give to the reduction of GHG emissions by improving thermal insulation requirement of the envelope. Additionally, the contribution to the reduction of environmental impacts, by taking into account the energy embodied in the building materials in relationship with the operational energy of the building, was indirectly experienced [86].

However, the defined methodology could be combined with other experimental assessment procedures, to be applied in the preliminary phase as a guide in the choice of a new use for abandoned buildings [87,88], and furthermore, this approach allows a quantification of the environmental profile of the built environment, promoting its reuse according to its real hidden environmental potential [89].

Author Contributions: Conceptualization, A.M.S. and S.D.M.; methodology, A.M.S. and S.D.M.; validation, A.M.S. and S.D.M.; case study data curation, A.M.S.; writing—original draft preparation, A.M.S. and S.D.M.; writing-review and editing, A.M.S. and S.D.M. All authors have read and agreed to the published version of the manuscript.

Funding: This research received no external funding.

Acknowledgments: The authors wish to thank Martina Uleri, author of the drawings included in the article, who granted the drawings used in this paper.

Conflicts of Interest: The authors declare no conflict of interest.

\section{References}

1. Greffe, X. Is Heritage an Asset or a Liability? J. Cult. Herit. 2004, 5, 301-309. [CrossRef]

2. Federation Federcasa Italian Housing. Housing Statistics in the European Union 2005/2006; Federation Federcasa Italian Housing: Rome, Italy, 2006. Available online: http://www.hofinet.org/upload_docs/Europe\%20Housing\%20Market $\% 20$ Statistics $\% 2005$ \%2006.pdf (accessed on 15 August 2021).

3. Gentili, M.; Hoekstra, J. Houses without People and People without Houses: A Cultural and Institutional Exploration of an Italian Paradox. Hous. Stud. 2019, 34, 425-447. [CrossRef]

4. Thomsen, A.; van der Flier, K.; Nieboer, N. Analysing Obsolescence, an Elaborated Model for Residential Buildings. Struct. Surv. 2015, 33, 210-227. [CrossRef]

5. Buitelaar, E.; Moroni, S.; De Franco, A. Building Obsolescence in the Evolving City. Reframing Property Vacancy and Abandonment in the Light of Urban Dynamics and Complexity. Cities 2021, 108, 102964. [CrossRef]

6. Pohoryles, D.A.; Maduta, C.; Bournas, D.A.; Kouris, L.A. Energy Performance of Existing Residential Buildings in Europe: A Novel Approach Combining Energy with Seismic Retrofitting. Energy Build. 2020, 223, 110024. [CrossRef]

7. Bon, R.; Hutchinson, K. Sustainable Construction: Some Economic Challenges. Build. Res. Inf. 2000, 28, 310-314. [CrossRef]

8. Ball, R.M. Re-Use Potential and Vacant Industrial Premises: Revisiting the Regeneration Issue in Stoke-on-Trent. J. Prop. Res. 2002, 19, 93-110. [CrossRef]

9. Caccavelli, D.; Gugerli, H. TOBUS-A European Diagnosis and Decision-Making Tool for Office Building Upgrading. Energy Build. 2002, 34, 113-119. [CrossRef]

10. De Valence, G. The construction sector system approach: An international framework. In Report by CIB W55-W65 Construction Industry Comparative Analysis Project Group; Carassus, J., Ed.; CIB: Rotterdam, The Netherlands, 2004. 
11. Gallant, B.T.; Blickle, F.W. The Building Decommissioning Assessment: A New Six-Step Process to Manage Redevelopment of Brownfields with Major Structures. Environ. Pract. 2005, 7, 97-107. [CrossRef]

12. Kohler, N. A European Perspective on the Pearce Report; Policy and Research. Build. Res. Inf. 2006, 34, 287-294. [CrossRef]

13. Bradley, P.E.; Kohler, N. Methodology for the Survival Analysis of Urban Building Stocks. Build. Res. Inf. 2007, 35, 529-542. [CrossRef]

14. Van Bueren, E.; De Jong, J. Establishing Sustainability: Policy Successes and Failures. Build. Res. Inf. 2007, 35, 543-556. [CrossRef]

15. Wilkinson, S.J.; James, K.; Reed, R. Using Building Adaptation to Deliver Sustainability in Australia. Struct. Surv. 2009, $27,46-61$. [CrossRef]

16. Bullen, P.A.; Love, P.E.D. The Rhetoric of Adaptive Reuse or Reality of Demolition: Views from the Field. Cities 2010, 27, 215-224. [CrossRef]

17. European Construction Industry Federation Statistical Report n. 64. Available online: https://fiec-statistical-report.eu/2021 / european-union (accessed on 30 August 2021).

18. European Commission A Renovation Wave for Europe-Greening Our Buildings, Creating Jobs, Improving Lives. Available online: https:/ / ec.europa.eu/energy/sites/ener/files/eu_renovation_wave_strategy.pdf (accessed on 15 December 2020).

19. Gaspar, P.L.; Santos, A.L. Embodied Energy on Refurbishment vs. Demolition: A Southern Europe Case Study. Energy Build. 2015, 87, 386-394. [CrossRef]

20. Stephan, A.; Crawford, R.H.; De Myttenaere, K. Towards a Comprehensive Life Cycle Energy Analysis Framework for Residential Buildings. Energy Build. 2012, 55, 592-600. [CrossRef]

21. Brennan, J.; Ding, G.; Wonschik, C.R.; Vessalas, K. A Closed-Loop System of Construction and Demolition Waste Recycling. In Proceedings of the 31st International Symposium on Automation and Robotics in Construction and Mining, ISARC 2014Proceedings, Sydney, Australia, 9-11 July 2014; pp. 492-498.

22. Hasik, V.; Escott, E.; Bates, R.; Carlisle, S.; Faircloth, B.; Bilec, M.M. Comparative Whole-Building Life Cycle Assessment of Renovation and New Construction. Build. Environ. 2019, 161, 106218. [CrossRef]

23. Li, C.Z.; Lai, X.; Xiao, B.; Tam, V.W.Y.; Guo, S.; Zhao, Y. A Holistic Review on Life Cycle Energy of Buildings: An Analysis from 2009 to 2019. Renew. Sustain. Energy Rev. 2020, 134, 110372. [CrossRef]

24. Mesa, J.A.; Fúquene-Retamoso, C.; Maury-Ramírez, A. Life Cycle Assessment on Construction and Demolition Waste: A Systematic Literature Review. Sustainability 2021, 13, 7676. [CrossRef]

25. Ortiz, O.; Castells, F.; Sonnemann, G. Sustainability in the Construction Industry: A Review of Recent Developments Based on LCA. Constr. Build. Mater. 2009, 23, 28-39. [CrossRef]

26. Cabeza, L.F.; Rincón, L.; Vilariño, V.; Pérez, G.; Castell, A. Life Cycle Assessment (LCA) and Life Cycle Energy Analysis (LCEA) of Buildings and the Building Sector: A Review. Renew. Sustain. Energy Rev. 2014, 29, 394-416. [CrossRef]

27. Cabeza, L.F.; Barreneche, C.; Miró, L.; Morera, J.M.; Bartolí, E.; Fernández, A.I. Low carbon and low embodied energy materials in buildings: A review. Renew. Sustain. Energy Rev. 2013, 23, 536-542. [CrossRef]

28. Ma, Z.; Cooper, P.; Daly, D.; Ledo, L. Existing building retrofits: Methodology and state-of-the-art. Energy Build. 2012, 55, 889-902. [CrossRef]

29. Gan, V.J.L.; Lo, I.M.; Ma, J.; Tse, K.T.; Cheng, J.C.; Chan, C.M. Simulation Optimisation towards Energy Efficient Green Buildings: Current Status and Future Trends. J. Clean. Prod. 2020, 254, 120012. [CrossRef]

30. Zabalza Bribián, I.; Valero Capilla, A.; Aranda Usón, A. Life Cycle Assessment of Building Materials: Comparative Analysis of Energy and Environmental Impacts and Evaluation of the Eco-Efficiency Improvement Potential. Build. Environ. 2011, 46, 1133-1140. [CrossRef]

31. Ellen Macarthur Foundation. Towards a Circular Economy Vol 1: An Economic and Business Rationale for an Accelerated Transition. Available online: https:/ / emf.thirdlight.com/link/x8ay372a3r11-k6775n/@/preview/1?o (accessed on 23 August 2021).

32. Lieder, M.; Rashid, A. Towards Circular Economy Implementation: A Comprehensive Review in Context of Manufacturing Industry. J. Clean. Prod. 2016, 115, 36-51. [CrossRef]

33. Strasser, S. Waste and Want: A Social History of Trash; Metropolitan Books: New York, NY, USA, 1999.

34. Steinhilper, R. Remanufacturing: The Ultimate Form of Recycling; Fraunhofer IRB: Stuttgart, Germany, 1998.

35. Zhu, J.; Fan, C.; Shi, H.; Shi, L. Efforts for a Circular Economy in China: A Comprehensive Review of Policies. J. Ind. Ecol. 2019, 23, 110-118. [CrossRef]

36. Mathews, J.A.; Tan, H. Progress toward a Circular Economy in China: The Drivers (and Inhibitors) of Eco-Industrial Initiative. J. Ind. Ecol. 2011, 15, 435-457. [CrossRef]

37. Congressional-Executive Commission on China. Circular Economy Promotion Law of the People's Republic of China. Available online: https: / / www.cecc.gov / resources /legal-provisions / circular-economy-promotion-law-of-the-peoples-republic-of-chinachinese (accessed on 5 September 2021).

38. Ellen MacArthur Foundation. What Is a Circular Economy? Available online: https://www.ellenmacarthurfoundation.org/ circular-economy / concept (accessed on 23 December 2020).

39. Lyle, J.T. Regenerative Design for Sustainable Development; Wiley: New York, NY, USA, 1994.

40. Mang, P.; Reed, B. Regenerative development and design. In Encyclopedia of Sustainability Science and Technology; Meyers, R., Ed.; Springer: New York, NY, USA, 2019. [CrossRef]

41. Keeble, B.R. The Brundtland Report: “Our Common Future”. Med. War 1988, 4, 17-25. [CrossRef] 
42. Gibson, E.J. Working with the Perfomance Approach in Building. Working Commission W60. CIB Report: Publication 64. 1982. Available online: https://www.irbnet.de/daten/iconda/CIB_DC23969.pdf (accessed on 23 August 2021).

43. Averill, J.D. Performance-Based Codes: Economics, Documentation and Design. Master's Thesis, Worcester Polytechnic Institute, Worcester, MA, USA, 1998.

44. Foliente, G.C.; Leicester, R.H.; Pham, L. Development of the CIB Proactive Programon Performance Based Building Codes and Standards, Doc 98/232. 1998. Available online: http:/ / citeseerx.ist.psu.edu/viewdoc/download?doi=10.1.1.129.8456\&rep=rep1 \&type $=$ pdf (accessed on 1 September 2021).

45. Becker, R. Fundamentals of Performance-Based Building Design. Build. Simul. 2008, 1, 356-371. [CrossRef]

46. Caterina, G. Tecnologia Del Recupero Edilizio; UTET: Torino, Italy, 1989.

47. Koutamanis, A.; van Reijn, B.; van Bueren, E. Urban Mining and Buildings: A Review of Possibilities and Limitations. Resour. Conserv. Recycl. 2018, 138, 32-39. [CrossRef]

48. Sharp, J.; Gilli Hobbs, H.; Henrotay, C.; Steinlage, M.; Debacker, W.; De Regel, S.; Sjögren, C. Framework for Policies, Regulations and Standards. 2019. Available online: https:/ / ec.europa.eu/research/participants/documents/downloadPublic?documentIds= 080166e5c11c69a1\&appId=PPGMS (accessed on 25 August 2021).

49. Rahla, K.; Mateus, R.; Bragança, L. Implementing Circular Economy Strategies in Buildings—From Theory to Practice. Appl. Syst. Innov. 2021, 4, 26. [CrossRef]

50. Villoria Sáez, P.; Osmani, M. A Diagnosis of Construction and Demolition Waste Generation and Recovery Practice in the European Union. J. Clean. Prod. 2019, 241, 118400. [CrossRef]

51. Whittaker, M.J.; Grigoriadis, K.; Soutsos, M.; Sha, W.; Klinge, A.; Paganoni, S.; Casado, M.; Brander, L.; Mousavi, M.; Scullin, M.; et al. Novel Construction and Demolition Waste (CDW) Treatment and Uses to Maximize Reuse and Recycling. Adv. Build. Energy Res. 2021, 15, 253-269. [CrossRef]

52. Addis, B. Building with Reclaimed Components and Materials: A Design Handbook for Reuse and Recycling; Routledge: London, UK, 2012. [CrossRef]

53. Pacheco-Torgal, F.; Ding, Y.; Colangelo, F.; Tuladhar, R.; Koutamanis, A. Advances in Construction and Demolition Waste Recycling: Management, Processing and Environmental Assessment; Elsevier: Amsterdam, The Netherlands, 2020.

54. Abioye, A.O.; Bhamidimarri, R. Upcycling Ideas for Sustainable Constructionand Demolition Waste Management: Challenges, Opportunities and Boundaries. Int. J. Innov. Res. Sci. Eng. Technol. 2017, 6, 4066-4079. [CrossRef]

55. Fogarassy, C.; Finger, D. Theoretical and Practical Approaches of Circular Economy for Business Models and Technological Solutions. Resources 2020, 9, 76. [CrossRef]

56. European Environment Agency Circular by Design. Products in the Circular Economy: Reuse, Repair, Redistribute, Refurbish, Remanufacture. 2017. Available online: https:/ / circulareconomy.europa.eu/platform/sites/default/files/circular_by_design_ __products_in_the_circular_economy.pdf (accessed on 10 August 2021).

57. Yuan, H.; Huang, Z.; Xu, P. A Framework for Eco-Efficiency of C\&D Waste Management. Procedia Environ. Sci. 2016, 31, 855-859. [CrossRef]

58. Giorgi, S.; Lavagna, M.; Campioli, A. Guidelines for effective and sustainable recycling of construction and demolition waste. In Designing Sustainable Technologies, Products and Policies; Benetto, E., Gericke, K., Guiton, M., Eds.; Springer: Cham, Switzerland, 2018. [CrossRef]

59. Ng, W.Y.; Chau, C.K. New Life of the Building Materials-Recycle, Reuse and Recovery. Energy Procedia 2015, 75, 2884-2891. [CrossRef]

60. Douglas, J. Building Adaptation; Butterworth Heinemann: Oxford, UK, 2006.

61. Brand, S. How Buildings Learn: What Happens after They're Built; Viking Press: New York, NY, USA, 1994.

62. Pomponi, F.; Moncaster, A. Circular Economy for the Built Environment: A Research Framework. J. Clean. Prod. 2017, 143, 710-718. [CrossRef]

63. Cole, R.J. Transitioning from Green to Regenerative Design. Build. Res. Inf. 2012, 40, 39-53. [CrossRef]

64. Pauli, G. UpSizing: The Road to Zero Emissions: More Jobs, More Income and No Pollution; Routledge: London, UK, 2017. [CrossRef]

65. Building Research Establishment. Sustainable Refurbishment-How to Better Understand, Measure and Reduce the Embodied Impacts. BRE. 2016. Available online: https:/ / www.bre.co.uk/ filelibrary/Briefing\%20papers/98660-Sustainable-Refurb-BriefingPaper.pdf (accessed on 20 August 2021).

66. Baker, H.; Moncaster, A.; Al-Tabbaa, A. Decision-making for the demolition or adaptation of buildings. Forensic Eng. 2017, 170, 144-156. [CrossRef]

67. Hammond, G.; Jones, C. Embodied energy and carbon in construction materials. Proc. Inst. Civ. Eng. Energy 2008, 161, 87-98. [CrossRef]

68. Hammond, G.; Jones, C. Embodied Carbon. The Inventory of Carbon and Energy (ICE), A BRSIA Guide; Lowrie, F., Tse, P., Eds.; University of Bath: Bath, UK, 2011. Available online: https://greenbuildingencyclopaedia.uk/wp-content/uploads/2014/07/ Full-BSRIA-ICE-guide.pdf (accessed on 16 August 2021).

69. Hebel, D.E.; Wisniewska, M.H.; Heisel, F. Building from waste: Recovered materials in architecture and construction. In Building from Waste: Recovered Materials in Architecture and Construction; Birkhäuser: Basel, Switzerland, 2014. 
70. Rasmussen, F.N.; Birgisdóttir, H. Life Cycle Environmental Impacts from Refurbishment Projects-A Case Study. In Proceedings of the CESB 2016-Central Europe towards Sustainable Building 2016: Innovations for Sustainable Future, Hong Kong, China, 22-24 June 2016.

71. Ferretti, V.; Grosso, R. Designing Successful Urban Regeneration Strategies through a Behavioral Decision Aiding Approach. Cities 2019, 95, 102386. [CrossRef]

72. Zanella, E.; Castiglioni, A. Urban Mining-Rigenerazioni Urbane; Corraini Edizioni: Mantova, IT, USA, 2016.

73. Berg, F.; Fuglseth, M. Life Cycle Assessment and Historic Buildings: Energy-Efficiency Refurbishment versus New Construction in Norway. J. Archit. Conserv. 2018, 24, 152-167. [CrossRef]

74. Preservation Green Lab. The Greenest Building: Quantifying the Environmental Value of Building Reuse, National Trust for Historic Preservation. 2011. Available online: https:/ /living-future.org/wp-content/uploads/2016/11/The_Greenest_Building. pdf (accessed on 16 August 2021).

75. CEN. Conservation of Cultural Heritage-Guidelines for Improving the Energy Performance of Historic Buildings; TC 346, EN 16883:2017; CEN: Brussels, Belgium, 2017.

76. Mickaityte, A.; Zavadskas, E.K.; Kaklauskas, A.; Tupenaite, L. The concept model of sustainable buildings refurbishment. Int. J. Strateg. Prop. Manag. 2008, 12, 53-68. [CrossRef]

77. Blengini, G.A. Life cycle of buildings, demolition and recycling potential: A case study in Turin, Italy. Build. Environ. 2009, 44, 319-330. [CrossRef]

78. Itard, L.; Klunder, G. Comparing environmental impacts of renovated housing stock with new construction. Build. Res. Inf. 2007, 35, 252-267. [CrossRef]

79. Ramírez-Villegas, R.; Eriksson, O.; Olofsson, O. Life Cycle Assessment of Building Renovation. Measures-Trade-off between Building Materials and Energy. Energies 2019, 12, 344. [CrossRef]

80. Leising, E.; Quist, J.; Bocken, N. Circular Economy in the Building Sector: Three Cases and a Collaboration Tool. J. Clean. Prod. 2018, 176, 976-989. [CrossRef]

81. Menzies, G.F. Embodied Energy Considerations for Existing Buildings: Technical Paper 13. Tech. Pap. 2011, 13, 53-68.

82. Settembre Blundo, D.; Ferrari, A.M.; Fernández del Hoyo, A.; Riccardi, M.P.; García Mui ña, F.E. Improving sustainable cultural heritage restoration work through life cycle assessment based model. J. Cult. Herit. 2018, 32, 221-231. [CrossRef]

83. Ferreira, J.; Pinheiro, M.D.; de Brito, J. Refurbishment decision support tools review-Energy and life cycle as key aspects to sustainable refurbishment projects. Energy Policy 2013, 62, 1453-1460. [CrossRef]

84. Filippi, M. Remarks on the green retrofitting of historic buildings in Italy. Energy Build. 2015, 95, 15-22. [CrossRef]

85. Pacheco-Torgal, F.; Granqvist, C.; Jelle, B.; Vanoli, G.; Bianco, N.; Kurnitski, J. (Eds.) Cost-Effective Energy Efficient Building Retrofitting Materials, Technologies, Optimization and Case Studies; Elsevier: Amsterdam, The Netherlands, 2017. Available online: https: / / www.sciencedirect.com/book/9780081011287/cost-effective-energy-efficient-building-retrofitting (accessed on 18 August 2021).

86. Palumbo, E.; Politi, S. Improving building envelope efficiency: Interaction between embedded Energy and operational energy. TECHNE-J. Technol. Archit. Environ. 2018, 16, 247-257. [CrossRef]

87. Wang, H.; Zeng, Z. A Multi-Objective Decision-Making Process for Reuse Selection of Historic Buildings. Expert Syst. Appl. 2010, 37, 1241-1249. [CrossRef]

88. Pinto, M.R.; De Medici, S.; Senia, C.; Fabbricatti, K.; De Toro, P. Building Reuse: Multi-Criteria Assessment for Compatible Design. Int. J. Des. Sci. Technol. 2017, 22, 165-193.

89. Fuertes, P. Embodied Energy Policies to Reuse Existing Buildings. Energy Procedia 2017, 115, 431-439. [CrossRef] 